\title{
The Role of Sea-Whip Coral (Leptogorgia sp.) as Habitat of Temperate Near-Shore Fish of Gulf of Mexico Jetties
}

\author{
Alyssa Squiers ${ }^{1} \&$ Kevin B. Strychar ${ }^{2}$ \\ ${ }^{1}$ Office of Sponsored Programs, Liberty University, Lynchburg, VA 24515, USA \\ 2 Annis Water Resources Institute, Grand Valley State University, Muskegon, Michigan 49441, USA \\ Correspondence: Kevin B. Strychar, Annis Water Resources Institute, Grand Valley State University, Muskegon, \\ Michigan 49441, USA.
}

Received: July 21, 2021

Accepted: September 20, $2021 \quad$ Online Published: November 18, 2021

doi:10.5539/ijb.v13n2p17

URL: https://doi.org/10.5539/ijb.v13n2p17

\begin{abstract}
Many fish species use intercoastal jetties throughout their life cycle to migrate to and from the ocean into bays and estuaries. During migration, fish may encounter rock, algae, sand, sea-grass, and coral. Anecdotal information indicates that some migrating fish of intercoastal jetties preferentially select colonies of gorgonian coral (Leptogorgia spp.) vs. any other habitat when encountering a predator. Since very little information exists regarding Leptogorgia, we focused our study in determining the importance of such coral as fish habitat. Stationary field sampling was conducted seasonally to determine the abundance of these coral, the type of migrating fish, and the habitat they associated with. Mesocosm studies were then conducted to determine whether Leptogorgia habitats are important to fish in the presence or absence of a predator. Five different habitats were compared (rock, algae, sand, Leptogorgia, and seagrass) and 6 species of fish (sergeant major, pinfish, mangrove snapper, spotfin mojarra, pigfish, and red drum). In the field study component, more than 600 colonies of Leptogorgia were observed and 17 different fish species. The most commonly observed fish were sergeant major, pinfish, mangrove snapper, and spotfin mojarra, however, sergeant majors were the most abundant species using coral as habitat. The use of mesocosms showed that all fish species significantly selected for structured habitat over non-structured habitat (e.g. sand), but that the fish commonly called 'sergeant major' significantly (ANOVA; $\mathrm{p} \leq$ 0.001) selected for Leptogorgia.
\end{abstract}

Keywords: coral, Leptogorgia, fish habitat, mesocosm, jetties, intercoastal waterways, Gulf of Mexico

\section{Introduction}

The intercoastal jetties of Texas (USA) are located on the western shore of the Gulf of Mexico (GOM). Constructed 100 years ago, they connect the GOM to the mainland via shallow hypersaline estuaries bordered by barrier islands (Britton \& Morton, 1989). Tidal inlets between barrier islands, much like the Port Aransas ship channel, are flanked by two parallel rock jetties that lie on either side of a dredged channel. These channels extend $2 \mathrm{~km}$ into the GOM and vary in width from $800 \mathrm{~m}$ to $2 \mathrm{~km}$. Texas jetties consist primarily of granite rock, creating crevices between the rocks for a variety of intertidal life (Britton \& Morton, 1989). Prior to their construction, hard shore biota was absent from the northwestern GOM (Britton \& Morton, 1989). These waterways provide high relief and complex habitats ideal for many reef-associated fish (Froeschke, Allen, \& Pondella, 2005; Mendelssohn et al., 2017). Distribution of flora and fauna within these jetties is influenced by wave exposure (Harley \& Helmuth 2003), tidal dynamics (Denny \& Paine 1998), temperature (Wethey 1983), and practical salinity (psu; Council of Science Editors, 2006) in which annual variations can range from $\sim 3$ to 45 and may fluctuate rapidly in the wet season (Britton \& Morton 1989; Orlando, Rozas, Ward, \& Klein, 1993); 3 psu we suspect only occurs during unusually wet seasons and considerable runoff. Distributions of other organisms, sessile and motile, vary seasonally, vertically, and horizontally and are also influenced by day length, light intensity and wave exposure.

Texas jetties are known for their high abundance of fish, including sport, bait, and aquarium traded fish (Britton \& Morton 1989; Jefferson, 2021). Many of these fish are not permanent residents and are found seasonally in different life stages thus making it an important nursery habitat (Lyndeman \& Snyder 1999, Baron, Jordan, \& Spieler, 2004). Habitat selection by fish occurs due to density dependent and independent factors (Rosenzweig, 1981). Density dependent factors include predation and food sources (Levin, Petrik, \& Malone, 1997). Fish have been observed to occupy habitats in which food sources and growth rates are maximized (Werner, Gilliam, Hall, \& Mittlebach, 1983). Life stage and size of the fish also affect habitat selection; selecting for areas with high or low flow/habitat complexity (Heggenes, 1996). Density 
independent factors include currents, weather, and climate and intensify density dependent factors as population size increases. Pinfish (Lagodon rhomboids, Linnaeus 1766), for example, are one of the most common and widely distributed fish species found along the Southeastern U.S. and GOM (Potthoff \& Allen, 2003; Ohs, DiMaggio, \& Grabe, 2011). Adult pinfish reproduce in coastal areas and post-larvae migrate into bays, where they remain until they return to the ocean as adults. Juvenile pinfish, during their migration into and out of bays, use submerged habitats such as mangroves, seagrass beds, salt marsh, and oyster reefs (Potthoff \& Allen, 2003). Sergeant major (Abudefduf saxatilis, Linnaeus 1758), adult mangrove snapper (sometimes called gray snapper; Lutjanus griseus, Linnaeus 1758), red drum (Sciaenops ocellatus, Linnaeus 1766), and sheepshead (Archosargus probatocephalus, Walbaum 1792) are also very common in jetty systems and like pinfish, live in complex habitats, such as outcroppings and ledges, seagrass beds, mangroves, and jetties (Burton, 2000; Nagelkerken, et al. 2000). Other habitats along the migration path into and out of bays, such as colonies of Leptogorgia sp. found on jetties may also be utilized, but the use of such coral has not been studied.

Several species of corals, including hermatypic corals (Astrangia and Oculina sp.; Cnidaria: Anthozoa: Scleractinia) and proteinacious gorgonians (Leptogorgia sp.; Cnidaria: Anthozoa: Gorgonacea: Gorgoniidae) have been observed on the jetties (Schultz, 1962). Williamson, Strychar and Withers (2011a) and Williamson, Strychar, Withers, and Sterba-Boatwright (2011b) observed more than 700 colonies of Leptogorgia sp. along the jetty system. In fact, Leptogorgia setacea (Pallas, 1766) and L. virgulata (Lamarck, 1815) are the two most common species observed on south Texas jetty systems and form large colonies/clumps (Williamson, Strychar, \&Withers, 2011a); in the Gulf of Mexico, nine species of Leptogoria have been described (Cairns and Bayer, 2009; Silvestri, Diguero, Hicks, Figueroa, 2019). Commonly called a sea whip coral, Leptogorgia sp. are colonial gorgonian corals that attach to hard substrates (DeVictor, 2005). Leptogorgia sp. range in color from orange to yellow with occasional free-floating strands of purple (e.g., $L$. setacea) (White \& Strychar, 2010). The exposed areas of hard bottoms are first colonized by a variety of algae, sponges and then corals that, in turn support a large diversity of fish and invertebrates (Street, Deaton, Chappell, \& Mooreside, 2005). Some regions of a jetty are also composed of a significant concentration of sandy substrates. Leptogorgia setacea has been observed to attach to and grow on the broken pieces of bivalve shells found in the sand. Complex branch formations created by Leptogorgia sp. are hypothesized to create a more structurally diverse habitat for both vertebrate and invertebrate pelagic and benthic organisms (Crowe, Blair, \& Pam, 2005). The structure may attract smaller organisms to the corals and local areas in search of suitable habitats. In a study conducted by Shultz (1962) and by Wicksten and Cox (2011), several important invertebrate fisheries species (e.g. Caridean and Penaeid shrimp, Penaeus sp.; and Blue crabs, Callinectes sapidus, Rathbun 1896) were observed in the local Aransas and Copano Bay systems in Texas. These invertebrates, secondarily, provide a food source for and attract many local marine fisheries species including, aquarium trade fish (e.g. sergeant major; Abudefduf sp.; Tabb, 1958; Powers, Peterson, Summerson, \& Powers, 2007), sport fish (e.g. mangrove snapper; Lutjanus sp.; Powers et al., 2007), and/or bait fish (e.g. pigfish, Orthopristis chrysoptera, Linnaeus 1766; Powers et al., 2007). Crowe et al. (2005) also observed that Leptogorgia sp. provided valuable habitat for many commercially and recreationally important fish (e.g. Black sea bass, Centropristis striata, Linnaeus 1758; mangrove snapper). These authors reported that fish (i.e. bass, snapper) are attracted to Leptogorgia sp. because they feed on the associated crustaceans (e.g. penaeid shrimp, blue crab; Peters \& McMichael, 1990). Some authors (see Shultz, 1962; Crowe, Blair, \& Pam, 2005) suggest that juvenile bass and snapper may also use the whip coral habitat for predator avoidance as they mature.

In many intercoastal jetties it is not known how important the gorgonian coral are as fisheries habitat (i.e. as food sources and/or predator avoidance). There are few studies concerning Leptogorgia sp. as a fish habitat (Schweitzer and Stevens, 2019) which may have implications for the corals' conservation, and fewer studies considering the importance of these coral as fish habitat in jetties. Wenker and Stevens (2020) suggest that given the importance of L. virgulata as common benthos habitat, however, this relatively understudied coral may be essential for some commercial important fish species. We hypothesize that migrating fish may use the coral, but more as habitat to avoid predation rather than habitat associated with ingestion of food material. We also hypothesize that fish which use gorgonian coral as habitat will be those that spend more time in the local area than those that frequently migrate.

\section{Material and Methods}

The study site in this project was the South Port Aransas Jetty ( $27^{\circ} 49.6^{\prime} \mathrm{N}$ and $\left.97^{\circ} 03.0^{\prime} \mathrm{W}\right)$ located in South Texas, USA (Figure 1). The Port Aransas Jetties are constructed of large granite rocks extending $\sim 1 \mathrm{~km}$ into the Gulf of Mexico (GOM). The jetty rocks provide hard substrate for coral attachment and help to create structural complexity in that environment. The average rainfall for the jetties area is $\sim 89.2 \mathrm{~cm} \mathrm{yr}^{1}$ (NOAA, 2021). The mean depth of the middle of the ship channel is $13.7 \mathrm{~m}$. Water temperatures range from $12.7^{\circ} \mathrm{C}$ in the winter to $29.4^{\circ} \mathrm{C}$ in the summer months (Texas Coastal Ocean Observation Network (TCOON) 2009). Salinities within the port Aransas ship channel range from 20 to 40 with annual means of 35 (TCOON 2009). 


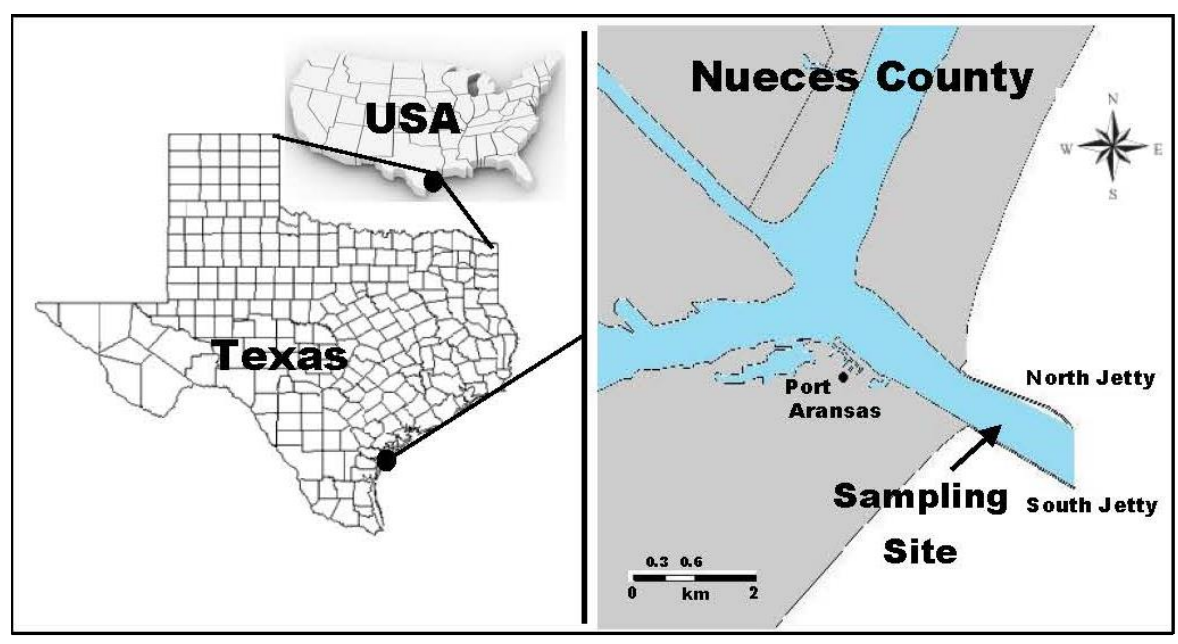

Figure 1. Map shows North and South jetties of the Port Aransas, Texas jetty system. Fish were enumerated along the inside (black arrow) of the South Jetty

\subsection{Field Sampling Methods}

In this study, a modified version of the Bohnsack and Bannerot (1986) stationary sampling method was used following Baron et al. (2004) in which the observer was able to move around and within an area being observed rather than maintaining a single stationary position. This method enables observers to enumerate fish that would have otherwise been hidden from sight (Baron et al., 2004). The stationary sampling method is based on six criteria: (1) all species of fish are included; (2) the method should require minimum setup time; (3) time in the water should be used efficiently; (4) the method should minimize experimental, observer, and behavioral bias; (5) data should generate estimates of species composition, abundance, frequency of occurrence and biomass; (6) sampling should include large economically and ecologically important species (Bohnsack \& Bannerot, 1986).

Bohnsack and Bannerot (1986) sampling stations were $7.5 \mathrm{~m}$ apart, however, in our study we used $10 \mathrm{~m}$ between stations to ensure each station would be statistically independent. Each sampling station was laid-out parallel to the channel side of the jetty (Figure 2a); note, we did not sample the seaward side due to dangerous

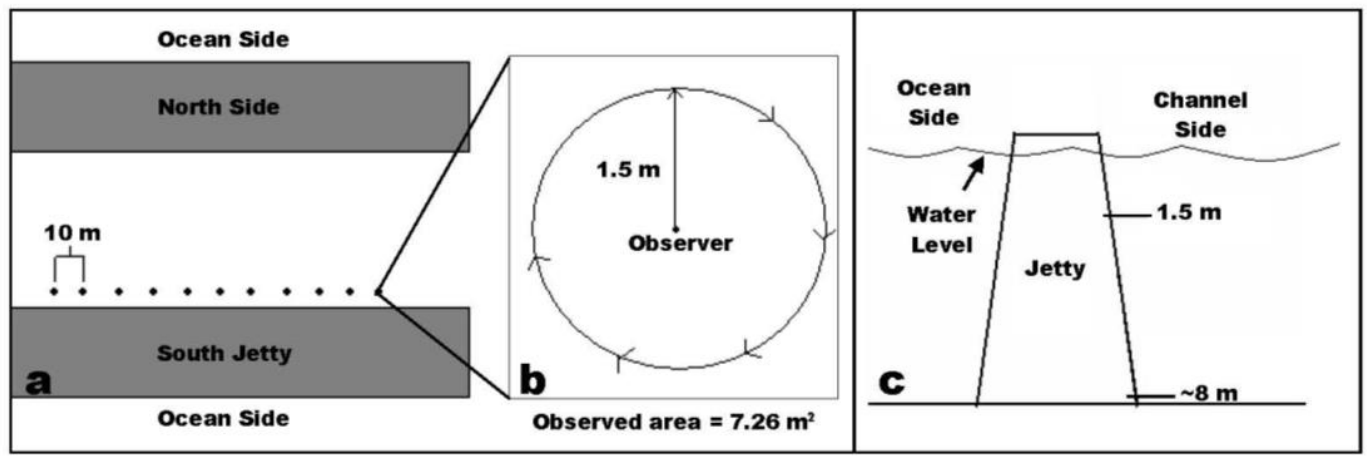

Figure 2. (a) Twelve stationary sampling sites located $10 \mathrm{~m}$ apart along the ship channel side of the Port Aransas, Texas south jetty; (b) One stationary sampling location showing orientation of observation and distance covered by observer; (c) Cross section of South Port Aransas jetty (Texas) displaying depths at $>1.5 \mathrm{~m}$ and $<1.5 \mathrm{~m}$. All fish were enumerated based on relative depth and association with coral habitat

undertows, rip currents, and safety considerations (Tissot, 2005). Each sampling period consisted of twelve total sampling sites and was divided between two to three days taking into account that conditions needed to be relatively similar during sampling dates. Four to six of the twelve stations were observed on the first day of sampling, the remaining were observed on the second or third sampling day. This process was repeated three times, which allowed for seasonal analyses consisting of early fall, late spring, and late summer. Winter sampling was not conducted due to poor water visibility resulting from increased re-suspension of sediments and high wave action and wind activity.

At each site, fish counts were conducted in which all but cryptic species (e.g. blennies and gobies) were documented. Fish within a $7.26 \mathrm{~m}^{2}$ circle around the observer were recorded over a $5 \mathrm{~min}$. period (Bohnsack \& Bannerot 1986). The distance 
around the observer was maintained using a measured piece of white PVC pipe $(1.5 \mathrm{~m})$. Any fish outside the reach of the measured pipe was not included in the count. The $5 \mathrm{~min}$. observation period was monitored using a digital underwater timer. Each stationary sample began facing the middle of the ship channel (Figure 2b), listing all species observed in the field of view (Bohnsack \& Bannerot 1986). Fish were categorized based on depth where water turbidity allowed a visual consensus either $\geq 1.5 \mathrm{~m}$ or $\leq 1.5 \mathrm{~m}$ (Figure $2 \mathrm{c}$ ). Nektonic species of fish were recorded and enumerated as they came into view as the observer maintained one position on the jetty and rotated in a clockwise direction, making a full circle at the end of the 5 min. observation period. The total number of each species of fish was counted according to season and site. During our fish counts, we did not discriminate between fish orientation, i.e. fish facing away from the jetty using the jetty as habitat since they could have simply been passing through the inlet using the jetty as an artificial reef habitat. Based on these numbers, abundance data was collected for each species of fish for each sampling season. Fish per meter squared was determined based on the fish counts.

\subsection{Mesocosm Laboratory Studies}

\subsubsection{Evaluating Habitat Selection in the Absence of a Predator}

A number of different methods were used to study fish behavior and habitat selection. In particular, the two commonly used laboratory selection studies include: (1) mesocosms (Rooker et al., 1998; Leclercq et al., 1999; Elliot \& Leggett, 1996; Póda \& Jordán, 2020); and (2) microcosms (Elliot \& Leggett, 1996). Boyle and Fairchild (1997), however, suggest that mesocosms are the best laboratory method as they allow for an enclosed ecosystem whose water chemistry and physical dimensions are known and controlled. Mesocosms characteristically include both natural species assemblages such as macrophytes and invertebrates, as well as structured populations of vertebrates (Boyle \& Fairchild, 1997; Póda \& Jordán, 2020)).

In this study, ten mesocosms were constructed from $81 \mathrm{~L}$ clear plastic tanks, each tank measuring $45.7 \times 66 \times 38.1 \mathrm{~cm}$. Knowing that a mesocosm is not simply dependent on its size, but also on the size of the organism placed within it, we used fish at the juvenile life stage. Non-vegetated habitat was simulated in all tanks by adding $6 \mathrm{~cm}$ of washed beach sand to the bottom of the tank. All other habitats were constructed on top of the sand bed. Each tank was filled with $\sim 76 \mathrm{~L}$ of filtered seawater. Water in the tanks was maintained at a psu of 35 and 22 to $25^{\circ} \mathrm{C}$ using a temperature-controlled room. Fluorescent lights on timers located throughout the room simulated a $12 \mathrm{~h}$ photoperiod.

Five different habitats were simulated in the mesocosms: (1) sea-whip coral (Leptogorgia sp.); (2) seagrass (Halodule wrightii, Ascherson 1868); (3) bare rock; (4) algae (Ulva lactuca, Linnaeus 1753 sp.); and (5) non-vegetated washed sand (sand was washed to remove extraneous debris). Each mesocosm tank was divided in half with each mesocosm combination established in different tanks. For example, each tank was divided, containing 50\% one habitat whilst the other $50 \%$ consisted of another habitat type (Stunz, Levin, \& Minello, 2001). Hence, each possible combination of habitats used in our experimental studies resulted in a maximum of ten possible combinations. Each treatment (i.e. habitat combination) was replicated twelve times (i.e. $n=12$ ) for each of six fish species used: Sergeant major fish, Pinfish, Mangrove snapper, Spotfin mojarra (Eucinostomus argenteus, Baird \& Girard 1855), Pigfish, and Red drum. Only one species of fish was used at any given time and all were used consecutively as they became available. Three fish of one species were removed from holding tanks, containing 100 fish and placed in each of the ten mesocosms. Each day, 30 fish were used. After a 12 to $18 \mathrm{~h}$ acclimation period within the mesocosms, the fish were observed every 30 min for a total of $5 \mathrm{~h}$, following a modified version of Stunz et al. (2001). At the end of a $5 \mathrm{~h}$ experimental time period, fish were removed. This process was repeated for 12 days for each species tested, resulting in 12 replicate trials (Stunz et al., 2001); a-prior power analysis was conducted using earlier data to help determine sample size. At the end of the 12 day experimental treatment, all fish were returned to the original collection site.

To minimize food effects on habitat selection during experimentation, fish were not fed within mesocosm tanks following Stunz \& Minello (2001). Habitats were simulated using local substrates and vegetation. Washed beach sand, for example, represented sand habitat. Cores of seagrass were used to simulate habitat. Similarly, strands of Leptogorgia sp. were used to represent coral habitat and Ulva sp. were used for algae habitats. Rocks from the Port Aransas and Packery Channel Jetties were also used to simulate rock habitats.

\subsubsection{Predator-Prey Habitat Selection}

Sergeant major fish were used in predation trials due to their high abundance on Port Aransas, Texas jetties. We used Pinfish as the experimental predator following Stunz \& Minello (2001), Stunz et al. (2001), and Beck \& Rooker (2012) who similarly used pinfish as a predator in their studies. It is acknowledged that pinfish are routinely used because of their abundance and ease of capture, and although Stoner (1980) indicate these fish only ingest minor amounts of fish prey in their diet, more recent authors, i.e. Beck \& Rooker (2012), suggest pinfish are natural predators known to feed on red drum larvae and juveniles (Fuiman, 1994; Rooker et al., 1998); juvenile pinfish are considered piscivorous when no other food items are available (Anonymous, 2021). It is well recognized, however, that pinfish are considered forage fishes 
(Faletti et al., 2019) showing preference to feeding on barnacles, shrimp, fish eggs, amphipods, insect larvae, and polychate worms. Juvenile Sergeant major fish were caught using dip nets on the Port Aransas, Texas south jetty from water depths ranging from 0 to $1 \mathrm{~m}$. Preliminary data indicated the mean abundance of Sergeant major fish at the study sites used for stationary sampling was $\sim 4$ fish $\mathrm{m}^{2}$. This mean abundance was representative of natural densities, but only three fish were used within mesocosms because preliminary estimates of abundance were conservative due the method used (i.e. stationary sampling; Bohnsack \& Bannerot, 1986) and the water conditions.

The experimental design using mesocosms and habitat described above in the absence of a predator was similarly used here with a predator. Two structured habitats, $L$. setacea, and bare rock were simulated within the mesocosms. Bare rock and $L$. setacea were used because of their high percent occurrence in the environment. Non-vegetated habitat (e.g. sand) was used as a control. Each tank was divided in half, containing 50\% one habitat whilst the other $50 \%$ consisted of another habitat type (Stunz et al., 2001). L. setacea with sand and L. setacea with rock were used as the experimental mesocosm habitats with each habitat occurring on each side of the tank an equal number of times. Four strands of $L$. setacea were used in each tank, representing coral habitat. The experimental treatment occurred for four days, allowing for twelve replicates of each mesocosm combination ( $L$. setacea/rock, L. setacea/sand). Each day, the mesocosms combination of $L$. setacea and rock occurred six times and L. setace $a$ and sand occurred six times.

Sergeant major fish were acclimated for 12 to $18 \mathrm{~h}$ in the mesocosm tanks, after which a predator was introduced and tethered onto one side of the mesocosm (Stunz \& Minello, 2001). Predators occurred on alternating sides of the tank, depending on the habitats being compared. A predator was tethered in the rock portion of the L. setacea/rock habitat twelve times and then in $L$. setacea portion of the mesocosm tank 12 times. This process was repeated for the tanks containing $L$. setacea and sand. The mesocosm treatments were observed for $5 \mathrm{~h}$, recording locations within the tank every $30 \mathrm{~min}$. After the $5 \mathrm{~h}$ period, the predators were removed from the tank and the remaining Sergeant major fish were returned to a holding tank. This process was repeated for four days, making a total of twelve $(n=12)$ replicate observations of each mesocosm per predator location combination (Stunz \& Minello, 2001).

\subsection{Statistics}

Data were checked for normality and heteroscedasticity of sample variances (Zar, 2010). If heteroscedasticity was found, the data were log transformed before analysis to homogenize the variances. For example, for each replicate mesocosm the percent occurrence of the organisms in each location was calculated. Mean percent occurrence was calculated and these data were arcsine transformed to normalize the distribution of the percentage data. Analysis initially consisted of paired student t-tests $(\alpha=0.05)$ followed by more rigorous parametric tests using an analysis of variance (ANOVA; IBM SPSS Statistics for Windows, version 28, IBM Corp., Armonk, N.Y., USA). To determine the sources of variance, estimated marginal means were used with the generalized linear model using Tukey's LSD post-hoc.

\section{Results}

\subsection{Field Sampling Methods}

A total of $120 \mathrm{~m}$ of the Port Aransas, Texas south jetty was sampled over three seasons. Water and air temperatures, salinity, turbidity, and water depths over the course of this study are shown in Table 1. Overall, 28 fish species were identified, classified in the families Pomacentridae, Labridae, Scaridae, Sparidae, Sciaenidae, Haemulidae, Gerreidae, Chaetodontidae, Lutjanidae, Serranidae, Ephippidae, Centropomidae, Scombridae, and Labrisomidae (Table 2,). Fall and summer sampling yielded more total fish per observation site than spring (Table A1). Site four, during early fall yielded the highest fish count with 83 total fish than spring sampling (Table A1). Site four, during early fall yielded the highest fish count with 83 total fish (Table A1). 
Table 1. Water parameter data from early fall (September-October), late spring (May-June), and late summer (July-August) sampling at the Port Aransas, Texas south jetty. Note: temp = temperature; ${ }^{\circ} \mathrm{C}=$ degrees Celsius; $p s u=$ practical salinity unit; $\mathrm{ntu}=$ nephelometric turbidity units; $\mathrm{m}=$ meters

\begin{tabular}{cccccc}
\hline Sampling Date & $\begin{array}{c}\text { Water Temp } \\
\left({ }^{\circ} \mathbf{C}\right)\end{array}$ & $\begin{array}{c}\text { Air Temp } \\
\left({ }^{\circ} \mathbf{C}\right)\end{array}$ & $\begin{array}{c}\text { Salinity } \\
(\mathbf{p s u})\end{array}$ & $\begin{array}{c}\text { Turbidity } \\
(\mathbf{n t u})\end{array}$ & $\begin{array}{c}\text { Water Depth } \\
(\mathbf{m})\end{array}$ \\
\hline \multicolumn{7}{c}{ Early Fall (September to October) } \\
26-Sep-08 & 26.6 & 27.2 & 30.8 & $1-2$ & 5.8 \\
10-Oct-08 & 26.1 & 26 & 30.3 & $0-1$ & 5.5 \\
\hline \multicolumn{7}{c}{ Late Spring (May to June) } \\
10-May-09 & 26.1 & 25.8 & 33.5 & 2 & 5.3 \\
31-May-09 & 27.7 & 26.6 & 32 & $0-1$ & 5.4 \\
25-Jun-09 & 29.5 & 28.8 & 37.7 & 13 & 5.5 \\
\hline \multicolumn{7}{c}{ Late Summer (July-August) } \\
27-Jul-09 & 25.5 & 31.1 & 32.9 & 4 & 5.4 \\
27-Aug-09 & 30 & 31.1 & 37.3 & 2 & 5.7 \\
\hline
\end{tabular}

Table 2. Twenty-eight species were observed and identified along the jetty system in Port Aransas, Texas; listed is the common, scientific, and family names, and species authority

\begin{tabular}{|c|c|c|c|}
\hline Common Name & Scientific Name & Family & Species Authority \\
\hline Sergeant major & Abudefduf saxaitlis & Pomacentridae & Linnaeus, 1758 \\
\hline Pinfish & Lagodon rhomboides & Sparidae & Linnaeus, 1766 \\
\hline Cocoa damsel & Pomacentrus variabilis & Pomacentridae & Castelnau, 1855 \\
\hline Mangrove snapper & Lutjanus griseus & Lutjanidae & Linnaeus, 1758 \\
\hline & & Gerreidae & Baird and Girard \\
\hline Spotfin mojarra & Eucinostomus argenteus & & in Baird, 1855 \\
\hline Pigfish & Orthopristis chrysoptera & Haemulidae & Linnaeus, 1766 \\
\hline Black drum & Pogonias cromis & Sciaenidae & Linnaeus, 1766 \\
\hline Spotfin butterflyfish & Chaetodon ocellatus & Chaetodontidae & Bloch, 1787 \\
\hline Rock hind & Epinephelus adscensionis & Serranidae & Osbeck, 1765 \\
\hline Atlantic spadefish & Chaetodipterus faber & Ephippidae & Broussonet, 1782 \\
\hline Sheepshead & Archosargus probatocephalus & Sparidae & Walbaum, 1792 \\
\hline Snook & Centropomus undecimalis & Centropomidae & Bloch, 1792 \\
\hline Hairy blenny & Labrisomus nисhipinnis & Labrisomidae & Quoy and Gaimard, 1824 \\
\hline Mackeral & Scomberomorus spp. & Scombridae & Lacepede, 1801 \\
\hline Slippery dick wrasse & Halichoeres bivittatus & Labridae & Bloch, 1791 \\
\hline Bucktooth parrotfish & Sparisoma radians & Scaridae & $\begin{array}{l}\text { Valenciennes in Cuvier } \\
\text { and Valenciennes, } 1840\end{array}$ \\
\hline Flagfin mojarra & Eucinostomus melanopterus & Gerreidae & Bleeker, 1863 \\
\hline Whip coral & Leptogorgia virgulata & Gorgoniidae & Lamarck, 1815 \\
\hline Whip coral & Leptogorgia setacea & Gorgoniidae & Pallas, 1766 \\
\hline Shoal grass & Halodule wrightii & Cymodoceacea & Aschers \\
\hline Sea lettuce & Ulva lactuca & Ulvacea & Linnaeus, 1753 \\
\hline Sea lettuce & Ulva fasciata & Ulvacea & Delile \\
\hline Red drum & Sciaenops ocellatus & Sciaenidae & Linnaeus, 1766 \\
\hline Littorina & Littorina lineolata & Littorinidae & D’Orbigny, 1840 \\
\hline Sea roach & Ligia exotica & Ligiidae & Roux, 1828 \\
\hline Stone crab & Menippe adina & Menippidae & A.B. Wiliams and Felder, 1986 \\
\hline Algae & Padina gymnospora & Dictyotaceae & Vickers \\
\hline Oyster drill & Stramonia haemastoma & Muricidae & Linnaeus, 1758 \\
\hline
\end{tabular}


Late spring produced the lowest count with 122 total fish (Table A1). Late summer produced the highest fish counts with 448 total fish (Table A1). Site 10 of late summer had the highest number of fish (75 total) for that season (Table A1). The four most abundant fish species observed (in order) were sergeant major, pinfish, mangrove snapper, and spotfin mojarra (Table 3).

Table 3. Three sampling seasons depicting fish abundances from stationary sampling; abundances measured in fish $\mathrm{m}^{-2}$

\begin{tabular}{lccc}
\hline & \multicolumn{3}{c}{ Abundance $\left(\mathbf{~ m}^{-2}\right)$} \\
\cline { 2 - 4 } \multicolumn{1}{c}{ Fish Observed } & $\begin{array}{c}\text { Early Fall } \\
\text { (September to October) }\end{array}$ & $\begin{array}{c}\text { Late Spring } \\
\text { (May to June) }\end{array}$ & $\begin{array}{c}\text { Late Summer } \\
\text { (July-August) }\end{array}$ \\
\hline Sergeant Major & 2.12 & 0.26 & 3.98 \\
Pinfish & 1.89 & 0.36 & 0.24 \\
Cocoa damsel & 0.11 & 0.00 & 0.08 \\
Mangrove snapper & 0.21 & 0.61 & 0.29 \\
Spotfin mojarra & 0.01 & 0.01 & 0.38 \\
Pigfish & 0.03 & 0.02 & 0.00 \\
Black drum & 0.01 & 0.00 & 0.00 \\
Spotfin butterflyfish & 0.00 & 0.00 & 0.01 \\
Rock hind & 0.06 & 0.01 & 0.06 \\
Spadefish & 0.07 & 0.00 & 0.00 \\
Sheepshead & 0.02 & 0.08 & 0.01 \\
Snook & 0.01 & 0.03 & 0.00 \\
Hairy blenny & 0.01 & 0.00 & 0.00 \\
Mackeral & 0.00 & 0.01 & 0.00 \\
Slippery dick wrasse & 0.00 & 0.00 & 0.03 \\
Bucktooth parrotfish & 0.00 & 0.00 & 0.02 \\
Flagfin mojarra & 0.00 & 0.00 & 0.03 \\
\hline
\end{tabular}

The coral $L$. virgulata was observed growing near the sand/rock interface at sites $8,9,10$, and 12 . At $\sim 1.5 \mathrm{~m}$, a juvenile mangrove snapper was observed at site 8 near the base of $L$. virgulata. Two colonies of $L$. virgulata were observed at site 9 at 1 to $2 \mathrm{~m}$. Sergeant major fish were observed at site 10 near a colony of $L$. virgulata at $\sim 1.5 \mathrm{~m}$. At 1 to $2 \mathrm{~m}$ depths, two colonies of $L$. virgulata were observed at site 12 .

\subsection{Evaluating Habitat Selection in the Absence of a Predator}

\subsubsection{Sergeant Major (Abudefduf saxatilis)}

Sergeant major fish were present through-out the year suggesting the jetties are likely used as spawning habitat (Foster 1987); these fish were observed at depths of $\leq 1 \mathrm{~m}$. Adults may have been present at deeper depths during sampling but were not observed (Nagelkerken et al., 2000). They were most abundant during late summer sampling at an abundance of 3.98 fish $\mathrm{m}^{2}$. Some selection for Leptogorgia sp., rock and algae occurred more often than non-vegetated sand bottom (Figure 3a). For instance, comparisons between structured habitats showed that sergeant major fish selected for algae more frequently than seagrass $(\mathrm{p}<0.001)$, Leptogorgia sp. more than algae $(\mathrm{p}=0.012)$, rock more than seagrass $(\mathrm{p}$ $<0.001)$, and sea whip coral more than seagrass ( $\mathrm{p}<0.001)$. Non-vegetated habitat was selected for more than seagrass ( $\mathrm{p}$ $=0.003$ ), although all other habitat comparisons showed that sergeant major fish selected for the structured habitats. 


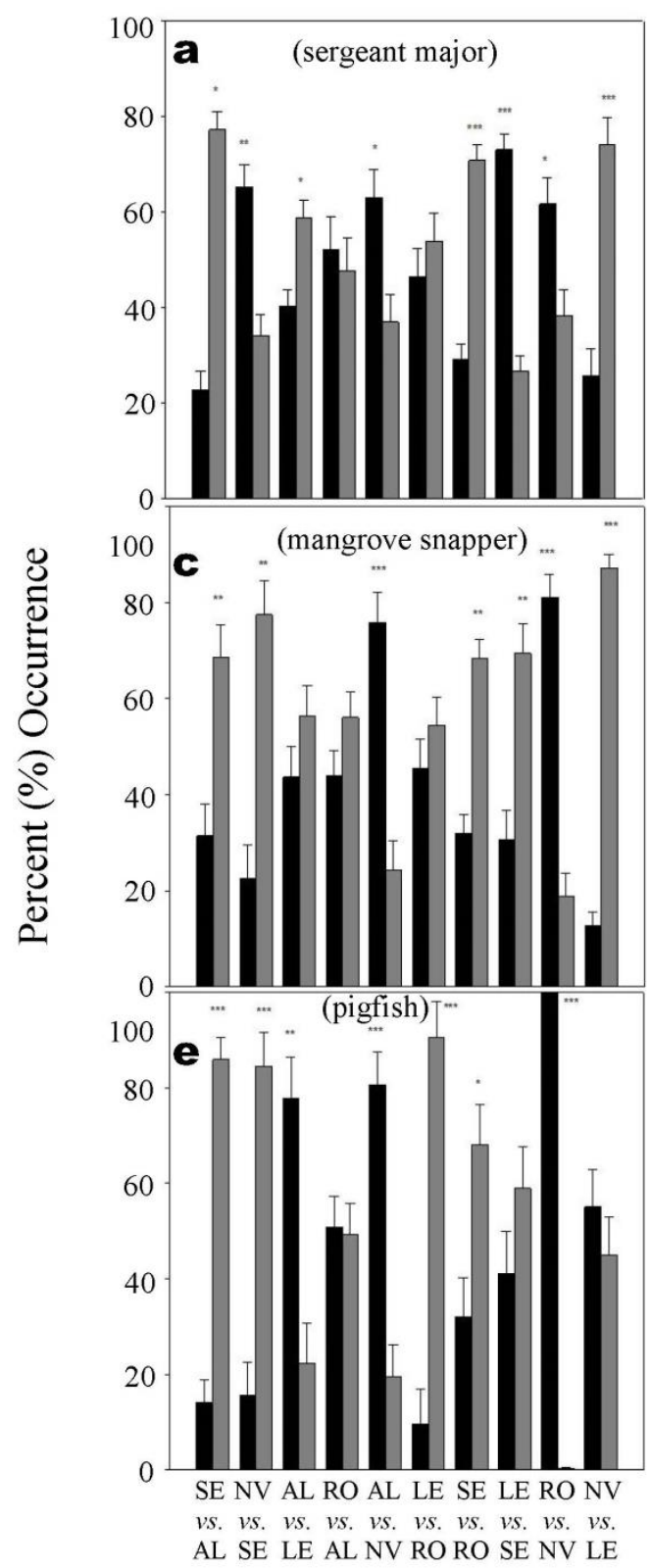

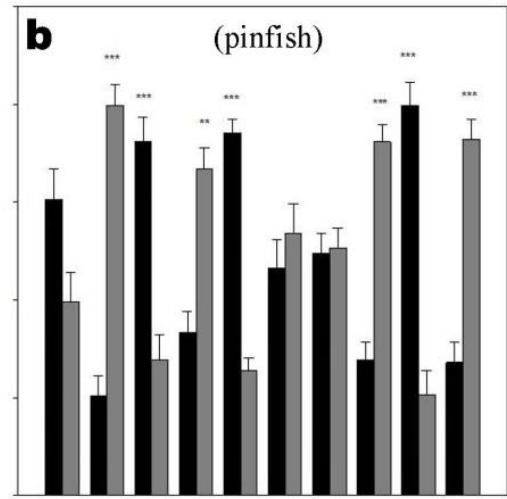
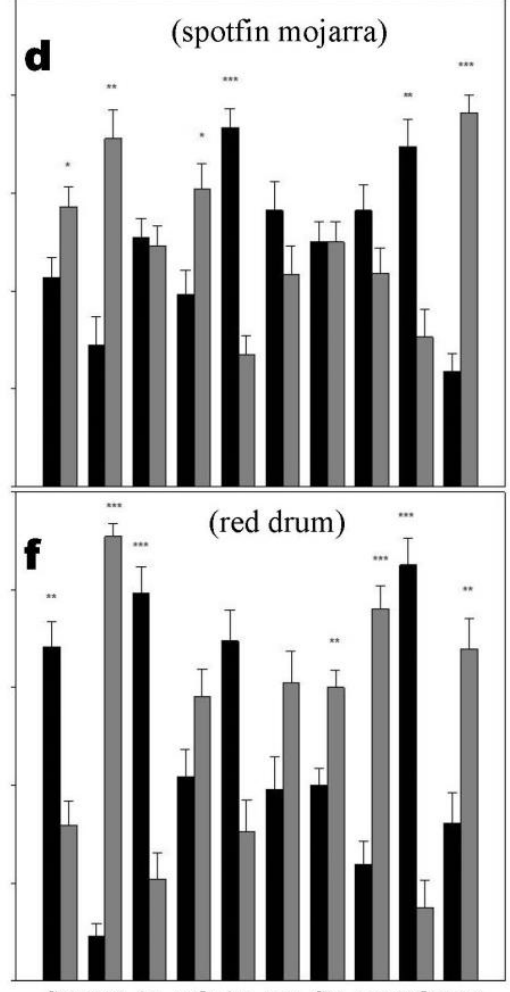

SE NV AL RO AL LE SE LE RO NV vs. vs. vs. vs. vs. vs. vs. vs. vs. vs. AL SE LE AL NV RO RO SE NV LE

Figure 3. Habitat selection by (a) sergeant major, (b) pinfish, (c) mangrove snapper, (d) spotfin mojarra, (e) pigfish, and (f) red drum within each mesocosm. Preference is expressed by percent. Habitats described are: $\mathrm{AL}=$ algae, LE $=$ Leptogorgia spp., $\mathrm{NV}=$ non-vegetated, $\mathrm{RO}=$ rock, $\mathrm{SE}=$ seagrass. Error bars are $\pm 95 \%$ standard error. Significance values represent paired habitat and are as follows: $*=<0.05 ; * *=<0.01 ; * * *=<0.001$

\subsubsection{Pinfish (Lagodon rhomboides)}

Pinfish were most abundant during early fall sampling at 1.89 fish $\mathrm{m}^{2}$. Pinfish showed strong selection for structured habitat, selecting for seagrass, algae, rock and Leptogorgia sp. more than non-vegetated sand bottom (Figure 3b). They selected seagrass more than Leptogorgia sp. ( $\mathrm{p}<0.001)$, and algae more than Leptogorgia sp. $(\mathrm{p}=0.002)$, and algae more than rock $(\mathrm{p}=0.002)$. No significant selection was observed between seagrass vs. algae $(\mathrm{p}=0.06)$, rock vs. Leptogorgia sp. $(\mathrm{p}=0.27)$, and rock vs. seagrass $(\mathrm{p}=0.43)$.

\subsubsection{Mangrove Snapper (Lutjanus griseus)}

Mangrove snapper were most abundant at 0.61 fish $\mathrm{m}^{2}$ during late spring sampling. Structured habitat comparisons showed that algae were selected more frequently than seagrass $(\mathrm{p}=0.008)$, rock more than seagrass $(\mathrm{p}=0.002)$, and seagrass more than Leptogorgia $\mathrm{sp} .(\mathrm{p}=0.005)$ (Figure $3 \mathrm{c})$. No significant selection was observed when comparing Leptogorgia sp., algae, and rock (Leptogorgia sp. vs. algae, $\mathrm{p}=0.16$; Leptogorgia sp. vs. rock, $\mathrm{p}=0.22$; and algae vs. rock, 
$\mathrm{p}=0.13$ ). When comparing non-vegetated bottom with structured habitats, mangrove snapper selected for the structured habitats more frequently (seagrass vs. non-vegetated, $\mathrm{p}=0.002$, algae vs. non-vegetated, $\mathrm{p}<0.001$; rock vs. non-vegetated, $\mathrm{p}<0.001$; and Leptogorgia sp. vs. non-vegetated, $\mathrm{p}<0.001$ ).

\subsubsection{Spotfin Mojarra (Eucinostomus argenteus)}

Spotfin mojarra were most abundant at 0.38 fish $\mathrm{m}^{2}$ during late summer sampling. When comparing structured habitats, they selected for algae more than seagrass $(\mathrm{p}=0.04)$ and algae more than rock $(\mathrm{p}=0.03)$ (Figure 3d). No significant selection was observed when comparing algae vs. Leptogorgia $\mathrm{sp} .(\mathrm{p}=0.42)$, Leptogorgia $\mathrm{sp}$. vs. rock $(\mathrm{p}=0.15)$, seagrass vs. rock $(\mathrm{p}=0.5)$, and Leptogorgia sp. vs. seagrass $(\mathrm{p}=0.12)$. Spotfin mojarra showed strong selection for all structured habitats when compared with non-vegetated bottom (seagrass vs. non-vegetated, $\mathrm{p}=0.004$; algae vs. non-vegetated, $\mathrm{p}$ $<0.001$; rock vs. non-vegetated, $\mathrm{p}=0.004$; and Leptogorgia sp. vs. non-vegetated, $\mathrm{p}<0.001$ ).

\subsubsection{Pigfish (Orthopristis chrysoptera)}

Patterns of selection showed that pigfish select algae more than seagrass $(\mathrm{p}<0.001)$, algae more than Leptogorgia $\mathrm{sp} .(\mathrm{p}=$ 0.009), rock more than Leptogorgia sp. $(\mathrm{p}<0.001)$, and rock more than seagrass $(\mathrm{p}=0.02)$ (Figure 3e). No significant selection was shown by pigfish when comparing rocks $v s$. algae $(\mathrm{p}=0.36)$ and seagrass vs. Leptogorgia $\mathrm{sp} .(\mathrm{p}=0.13)$. Non-vegetated habitat was selected for over Leptogorgia sp. although it was not significant $(\mathrm{p}=0.22)$. All other habitat comparisons between non-vegetated sand bottom and structured habitats showed that pigfish selected for the structured habitats (seagrass $v s$. non-vegetated, $\mathrm{p}<0.001$; algae $v s$. non-vegetated, $\mathrm{p}<0.001$; and rock $v s$. non-vegetated, $\mathrm{p}<0.001$ ).

\subsubsection{Red Drum (Sciaenops ocellatus)}

Red drum selected for seagrass more than algae $(\mathrm{p}=0.002)$, algae more than Leptogorgia $\mathrm{sp} .(\mathrm{p}<0.001)$, rock more than seagrass $(\mathrm{p}=0.008)$, and seagrass more than Leptogorgia sp. $(\mathrm{p}<0.001)$ (Figure $3 \mathrm{f})$. In trials comparing algae vs. rock ( $\mathrm{p}$ $=0.08)$ and rock vs. Leptogorgia $\mathrm{sp} .(\mathrm{p}=0.06)$, red drum did not display significant habitat selection. Red drum selected for structured habitats when compared with non-vegetated bottom (seagrass vs. non-vegetated, $\mathrm{p}<0.001$; algae vs. non-vegetated, $\mathrm{p}=0.07$; rock vs. non-vegetated, $\mathrm{p}<0.001$; and Leptogorgia sp. vs. non-vegetated, $\mathrm{p}=0.01$ ).

\subsection{Predator-Prey Habitat Selection}

The presence of a potential predator did not alter habitat selection for sergeant major fish. Without predators, sergeant major fish selected for structured habitats (Figure 3b), with the exception of seagrass, more than sand. When a predator was introduced, habitat selection was not dependent upon the location of the predator (Figure 4a,b). For instance, adding a predator to the sand habitat (previously selected against; Fig. 3b) had little effect on the habitat selection pattern (Figure $4 a, b)$.

When comparing structured habitats, sergeant majors selected for Leptogorgia sp. with pinfish more frequently than habitats with rock $(\mathrm{p}=0.01)$ and Leptogorgia $\mathrm{sp}$. over rock with pinfish $(\mathrm{p}<0.001$; Figure $4 \mathrm{a}, \mathrm{b})$. Structured habitats, when compared with the non-vegetated habitat were significantly selected for, regardless of predator location (Leptogorgia sp. vs. sand with pinfish, $\mathrm{p}=0.005$; rock vs. sand with pinfish, $\mathrm{p}<0.001$; rock with pinfish vs. sand, $\mathrm{p}<$ 0.001; Leptogorgia sp. with pinfish vs. sand, $\mathrm{p}<0.001$ ).

\section{Discussion}

Inter-coastal waterways and human developments such as jetty systems are home to many different species of fish because of the abundance of habitat (e.g. rocks, algae, coral, and sand). The importance of these habitats, however, is poorly studied and their contribution to fishery ecology is lacking. For example, the role gorgonian corals (e.g. Leptogorgia sp.) have on the ecosystem is unknown and yet they exist in high concentrations (Williamson et al., 2011a). These coral are not protected by fisheries and consequently are collected by aquarists without regard to their survival or the potential impact to other species (e.g. fish).

\subsection{Field Sampling Methods}

A variety of methods exist to quantify fish associated with a particular habitat. Two of the most commonly used methods include the transect method and rapid visual census techniques, however, they suffer from problems making them inadequate for sampling reef fish structure (Bohnsack \& Bannerot, 1986; Caldwell, Zgliczynski, Williams, \& Sandin, 2016; Pais \& Cabral, 2018). DeMartini and Roberts (1982), Caldwell et al. 

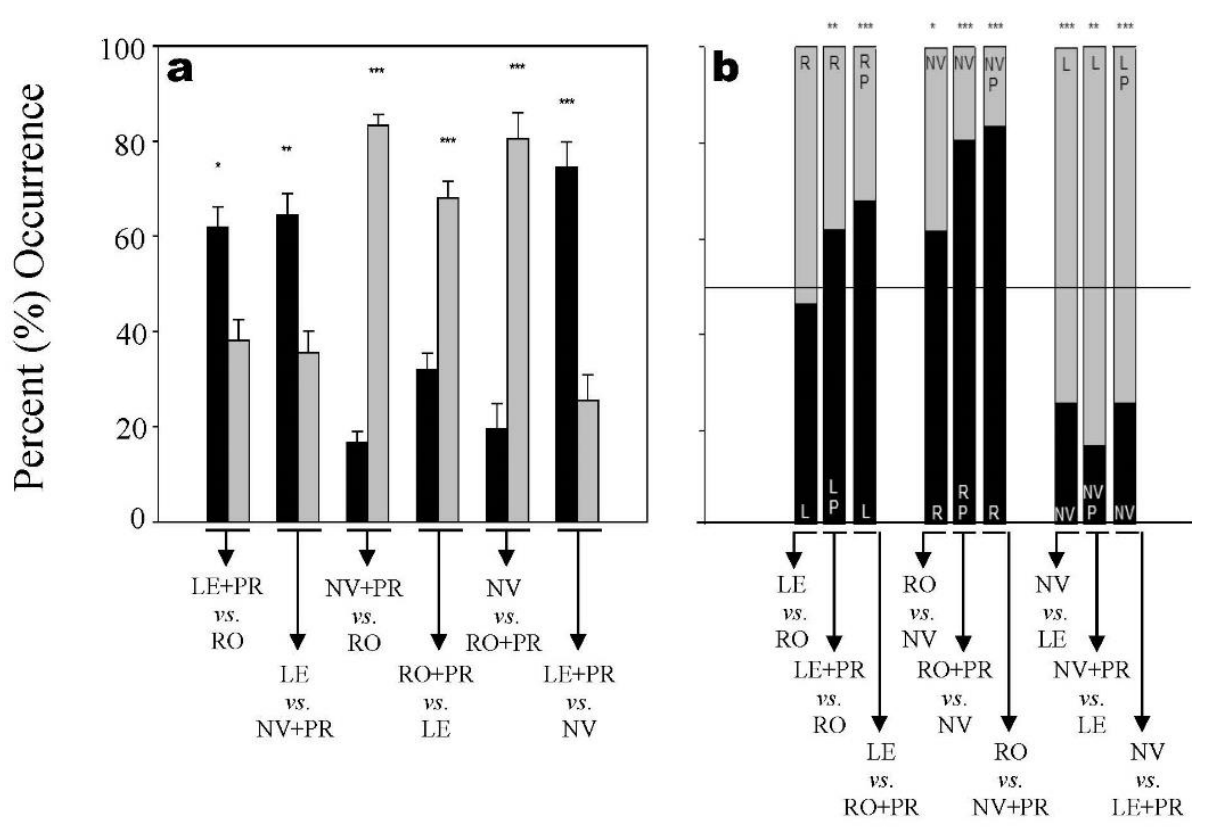

Figure 4. (a) Sergeant major habitat selection in the presence of a predator. Habitats are described accordingly: LE+PR vs. $\mathrm{RO}=$ Leptogorgia spp. plus predator vs. rock without a predator, $\mathrm{LE}$ vs. $\mathrm{NV}+\mathrm{PR}=$ Leptogorgia spp. without a predator vs. non-vegetated habitat plus predator, $\mathrm{NV}+\mathrm{PR}$ vs. $\mathrm{RO}=$ non-vegetated habitat plus predator vs. rock without a predator, $\mathrm{RO}+\mathrm{PR}$ vs. $\mathrm{LE}=$ rock plus a predator vs. Leptogorgia spp. without a predator, $\mathrm{NV}$ vs. $\mathrm{RO}+\mathrm{PR}=$ non-vegetated habitat

without a predator vs. Leptogorgia spp. plus predator, and LE+PR vs. NV = Leptogorgia spp. plus predator vs. non-vegetated habitat without a predator. Error bars represent $\pm 95 \%$ standard error. (b) Sergeant major habitat selection with and without a predator. Habitats studied are: LE vs. RO = Leptogorgia spp. vs. Rock without a predator, LE+PR vs. $\mathrm{RO}=$ Leptogorgia spp. plus predator vs. rock without a predator, $\mathrm{LE}$ vs. $\mathrm{RO}+\mathrm{PR}=$ Leptogorgia spp. without a predator vs. rock plus a predator, $\mathrm{RO}$ vs. $\mathrm{NV}=$ rock vs. non-vegetated habitat without a predator, $\mathrm{RO}+\mathrm{PR}$ vs. $\mathrm{NV}=$ rock plus a predator vs. non-vegetated habitat without a predator, $\mathrm{RO} v \mathrm{vs.} \mathrm{NV}+\mathrm{PR}=$ rock without a predator vs. non-vegetated habitat plus predator, $\mathrm{NV}$ vs. $\mathrm{LE}=$ non-vegetated without a predator vs. Leptogorgia spp. without a predator, $\mathrm{NV}+\mathrm{PR}$ vs. $\mathrm{LE}=$ non-vegetated habitat plus predator vs. Leptogorgia spp. without a predator, and NV vs. LE+PR $=$ non-vegetated without a predator vs. Leptogorgia spp. plus predator. Also for clarity, within each bar R = Rock, L = Leptogorgia spp., NV = non-vegetated sand habitat, and $\mathrm{P}=$ predator. Significance values represent paired habitat and are as follows: $*=<0.05$;

$$
* *=<0.01 ; * * *=<0.001
$$

(2016) and Pais and Cabral (2018) evaluated the rapid visual technique and determined that this method over emphasizes rare fish species, species moving in/out after observations has started, and under-emphasizes patchy although abundant species. The visual transect census, described by Sale and Sharpe (1983), underestimates fish densities, which are dependent upon the width of the transect (see also Willis, 2001; Thanopoulou et al., 2018). Pais and Cabral (2018) suggested that when using transects to enumerate fish, swimming speed had an effect on sample counts. At fast swimming speeds, small cryptic fish were underestimated and at slow swimming speeds highly mobile species were overestimated (Smith, 1988). Two additional methods also widely used in marine studies involve the use of the chemicals Rotenone ${ }^{\odot}$ and Clove oil ${ }^{\odot}$ (Ackerman \& Bellwood, 2002). Although both chemicals are relatively useful and provide quantitative samples, these methods are also more destructive (Ackerman \& Bellwood, 2002); rotenone is an ichthyocide whereas clove oil is an anesthetic. Ferro et al. (2005) and Baron et al. (2004) propose using the Bohnsack \& Bannerot (1986) stationary sampling method to enumerate fish. Stationary sampling, unlike other methods is a non-destructive method in which fish within a habitat can be counted with limited interference from the observer. Using this method we determined that the most abundant species of fish observed on the jetty associated with Leptogorgia spp. was the sergeant major. Juvenile sergeant major fish were most abundant at sites with the most diverse and complex habitats and were found throughout the top $1 \mathrm{~m}$ of water. When turbidity concentrations were low, sergeant major and mangrove snapper fish were observed in close proximity or hiding between stands of sea whip coral. With few similar studies to compare to, further research needs to be done on the abundance of local fish populations and factors that affect those populations in association to sea whip coral. For example, water temperatures and salinity in addition to clarity/turbidity may play a vital role in determining what species are present and whether fish associate with such coral (Buxton \& Smale, 1989). 
In this study, water temperatures on the Port Aransas jetties varied by $4.9^{\circ} \mathrm{C}$ between all three sampling seasons. Variations in temperatures and salinity affect recruitment to inshore habitats during the first several years of life for many fish species (Drinkwater \& Myers, 1987; Régnier, Gibb, \& Wrights, 2019; Jaureguizar, De Wysiecki, Camiolo, \& Clara, 2021). Many commercial, recreational, and aquarium-traded fish use estuaries and associated habitats as nursery grounds because estuaries act as thermal buffers against open-sea conditions (Blaber \& Blaber 2006; Hughes et al., 2014). High abundances of several fish species (sergeant major, pinfish, and mangrove snapper) observed in our study may not only be attributed to the presence of coral, but to a broad thermal tolerance which may be necessary for life within a jetty system (Blaber \& Blaber, 2006). Water temperatures were coldest during the early fall sampling, potentially excluding several fish species only observed in the late summer (e.g. spotfin butterflyfish, slippery dick wrasse, bucktooth parrotfish, and flagfin mojarra). The spotfin butterfly fish and slippery dick wrasse are usually found in warmer waters and only occur inshore seasonally, when water temperatures are favorable (Phelps \& Williams, 1995). Spotfin butterflyfish and slippery dick wrasse are known to migrate offshore in the winter and return in the spring (Phelps \& Williams, 1995). Many species of fish (juveniles and/or adults) are found year-round migrating into and out of the channel, independent of temperature. These species include the sergeant major, pinfish, mangrove snapper, pigfish, cocoa damsel, spotfin mojarra, black drum, and rock hind (Hoese \& Moore, 1998; Fangue et al., 2001, Wuenschel, Jugovich, \& Hare, 2004; Rummer et al., 2009; pers. obsv.).

Salinity also has an affect on the presence/absence of fish on a jetty system (Shervette, Ibarra, \& Gelwick, 2007; Arceo-Carranza \& Vega-Cendejas, 2009). Salinity creates a physiological barrier for some species (Arceo-Carranza \& Vega-Cendejas, 2009). Extreme salinities combined with extreme high or low temperatures can result in mortality (Wuenschel et al., 2004). Most fish found year-round on the Port Aransas jetty can withstand the changes in salinity, which varied from 32 to 37. Pinfish, for example, can withstand salinities ranging from 0 to 75 (Shervette et al., 2007; Ohs, Grabe, \& DiMaggio, 2018). Low salinities were observed in the early fall sampling season and highest salinities occurred during the late summer sampling when there was little to no rain. These changes in salinity throughout the seasons in combination with warmer temperatures most likely affected fish occurrence (e.g. presence/absence of spotfin butterflyfish, slippery dick wrasse, bucktooth parrotfish, and flagfin mojarra).

Water clarity/turbidity is also an important factor in determining whether fish associated with coral. Turbidity measurements taken at the start of each stationary sampling site varied throughout the day and sometimes disrupted the ability to clearly characterize fish species and their behavior associating with coral at specific sampling sites. Water clarity was affected by proximity to the mouth of the jetty vs. proximity to the backside of the jetty. Using data provided by TCOON (2009), it was observed as tides changed throughout the day (high tide), clearer water entered the channel. Out-going tides, however, contribute to more turbid conditions because of the sediment that is re-suspended in the water column. Turbidity measurements during stationary sampling were generally low (0 to 4$)$ allowing for clear visibility above $\sim 1 \mathrm{~m}$ in depth. Below 1 to $1.5 \mathrm{~m}$, turbidity increased, limiting visibility. Although 17 species of fish were recorded, other species may have been present but not observed due to turbidity at deeper depths. It was also not always possible to determine fish and habitat associations (e.g. coral, rock etc.) due to turbidity. While turbidity was a hindrance to sampling, high turbidity may be important to fish living within the turbid waters (Blaber \& Blaber, 2006). Predation on small prey species or juvenile fish may be reduced because of limited visibility (Snow, Shoup, \& Porta, 2018). Reduced predation may result in higher fish abundance. Although this study did not observe the entire length of the jetty system, Williamson et al. (2011a, b) completed a thorough assessment of Leptogorgia spp. coral colonies and suggests that sea whip coral exist along the entirety of the jetty. It is conceivable, therefore, that fish species identified in specific sampling sites studied here use this habitat from the jetty mouth to the jetty backside.

Other factors contributing to fish abundance include food sources, predators, and potential nursery areas. Sergeant major fish forage in the water column and near the rocks and therefore do not generally stray far from their associated structure (Davis \& Birdsong, 1973; Alves et al., 2016). As fish migrate from one habitat to the next with ontogeny, their food habits also change (Cocheret de la Moriniere, Pollux, Nagelkerken, \& van der Velde, 2003). Migration typically occurs when adults, juveniles, or larvae seek out nursery or reproduction areas. Nursery areas are often used for predator avoidance and abundant food sources (Nagelkerken et al, 2000; Beck et al., 2001). It is unclear whether colonies of Leptogorgia sp. found on the jetties can be considered nursery areas, but they do connect with nursery areas found within associated bays (Nagelkerken et al., 2001).

\subsection{Mesocosm Laboratory Studies}

Adult and juvenile marine fish use estuarine and associated environments for food, habitats and predator avoidance (Stunz, Minello, \& Levin, 2002; Neahr, Stunz, \& Minello, 2010). Submerged vegetation has been documented as important juvenile habitats (Stunz et al., 2002; Fischer et al., 2018), however, prior to this study it was unknown whether any fish species use the Leptogorgia spp. colonies as habitat. Laboratory mesocosms were used to assess habitat selection because they allow for controlled environmental conditions (e.g. food availability, presence of a predator; Fischer, 2000). This 
study showed that Leptogorgia sp. is important to various species of fish on the Port Aransas jetties. This study also demonstrated how one species of fish, the sergeant major, in the presence of a potential predator, did not alter habitat selection.

\subsubsection{Sergeant Major (Abudefduf saxatilis)}

The general habitat selection of sergeant major fish (an aquarium traded fish) in laboratory mesocosms reflects habitat selection that may be seen in a natural setting. Sergeant major fish did not select for seagrass habitats because seagrass is found bayward of the Port Aransas jetties. Sergeant majors do not migrate to spawning sites and are rarely found outside of their typical habitats (e.g. reefs, rocks etc.; Robertson, 1988, Nagelkerken et al., 2000). Rock, algae, Leptogorgia sp., and sand are all found within their natural habitat within and around the Port Aransas jetties (pers. obser.). Habitat selection for Leptogogia sp. within the mesocosm setting may be due to high densities of fish on the jetty using the coral as hiding space (Nagelkerken, 1974). Other habitats selected for (rocks and algae) may have been chosen because they also provide hiding spaces from predators as well as food sources, e.g. plankton and invertebrates (Nagelkerken, 1974, Briton \& Morton, 1989). Sand was not selected due to a lack of habitat complexity. Cryptic coloration, an adaptation against visual detection by predators, may have also been another factor leading to the selection of Leptogorgia sp. habitats (Main, 1987). The yellow vertical bars of the sergeant major closely resemble the yellow - orange coloration of the coral. This color resemblance reduces vulnerability to predators who depend upon sight (Main, 1987; Merilaita, 1999). Alternatively, the use of juveniles in the mesocosms study may have also played a role in habitat selection. Juveniles are known plankton feeders, whereas adults are preferentially benthic feeders (Davis \& Birdsong, 1973). If adults were used in this study, habitat selection may have varied slightly due to ontogenetic shifts.

The introduction of a potential predator into the mesocosms did not alter the habitat selection of the sergeant major. In a laboratory setting, pinfish are frequently observed to be voracious predators of larval fishes (Shervette, Ibarra, \& Gelwick, 2007), but it is well recognized they are not a natural predator of fish. In this study, it is plausible that the behavioral response (or lack thereof) by sergeant major may be related to the fact that they do not normally perceive pinfish as a predatory threat. Structured habitat, however, was still selected for over unstructured habitat and Leptogorgia sp. and rock were selected for independent of our potential predator location. Other species of fish (e.g. red drum) are known to select for structured habitats when in the presence of a predator (Rooker, G. Holt, \& S. Holt, 1998).

\subsubsection{Pinfish (Lagodon rhomboides)}

Pinfish are estuarine dependent and spawn in offshore waters (Shervette et al., 2007). Post larvae are transported into estuaries where they mature to juveniles (Shervette et al., 2007). Migration of juveniles out of estuaries through inlets (jetties) occurs in spring and summer (Muncy, 1984). During their migration pinfish encounter all habitats used within the mesocosm study. Juveniles prefer structurally complex habitats much like those found along the Port Aransas jetty (Dahlberg, 1972). Pinfish habitat selection varied dependent upon the habitats being compared. They preferred structured habitats over non-structured habitats (e.g. seagrass, rock, Leptogorgia sp., algae) but did not show significant selection when comparing the most structured habitats (e.g, seagrass vs. rock and Leptogorgia sp. vs. rock). We speculate that Pinfish may be selecting seagrass and coral preferentially because they can effectively use cryptic coloration as a deterrent to predators (Main, 1987). We noticed that a single habitat is not significantly more important than all others. All habitats, with the exception of the non-vegetated sand bottom, were selected for and may be of importance to the pinfish in an estuarine/jetty environment.

\subsubsection{Mangrove Snapper (Lutjanus griseus)}

Mangrove snapper, much like pinfish, did not specifically select for one jetty habitat over another habitat, making all habitats equally important. Mangrove snapper, known as an important fisheries species, occupy a variety of habitats throughout their life cycle (Burton, 2000; Yeager et al., 2014; Bacheler et al., 2020). Adults spawn off-shore and are found near complex offshore habitats whereas juveniles and larvae are found inshore. Whilst adults feed on larger food items and will increase their foraging radius (Cocheret de la Moriniere, 2003), juveniles feed primarily on non-decapod crustaceans, specifically Penaeid shrimp (Hettler, 1989). Hence seagrass beds, mangroves as well as jetties are important juvenile habitat (Burton, 2001). Consequently, seagrass was significantly selected as a habitat of preference, but this may be explained by the fact that seagrass is an abundant habitat where many juvenile mangrove snapper can be found. Seagrass is also considered a nursery habitat where-as habitats found within the jetty system are used as the fish are growing and migrating offshore (Nagelkerken, 2000; Nagelkerken, 2001).

\subsubsection{Spotfin Mojarra (Eucinostomus argenteus)}

Spotfin mojarra, an abundant bait fish, are estuarine dependent and are known to migrate within local bays (Branco, Aguiaro, Esteves, Caramaschi, 1997). A study conducted by Kershner et al. (1985) reported mojarra on shallow reefs, but also observed that they were highly abundant within a local inlet connecting the Atlantic Ocean to a river. Although they 
are known to live within jetty systems, they were not observed to show any specificity for Leptogorgia sp. as habitat. Algae (Ulva sp.), an abundant habitat found on the Port Aransas jetty was significantly selected whereas habitat comparisons between all other structured habitats were not significant. It is plausible that feeding preferences played an important role in overall habitat selection. Mojarra are primarily benthic feeders, consuming prey found near the sand/rock interface (Branco et al., 1997). Algae, polychaetes, and copepods make up a large portion of the diet consumed by the fish (Abu El-Nasr, 2015)). Mojarra are also a schooling fish and may not seek refuge from predators within habitats but rather rely on numbers (Kershner et al. 1985). Much like pinfish and mangrove snapper, a single habitat may not be more important than others.

\subsubsection{Pigfish (Orthopristis chrysoptera)}

Pigfish are another species of bait fish found locally. Although the pigfish did significantly select for structured habitats their behavior within the mesocosms should be considered. Movement within the tank was limited and they generally stayed within the original habitat they settled into. We speculate this may be attributed to their unfamiliarity with the habitat and given an option of more open-space, they may have preferred a pelagic environment. Sutter and McIlwain (1987), for example, describe pigfish as more abundant offshore than inshore. Alternatively, Pigfish are also known as prey species for small sharks and spotted seatrout (Cynoscion nebulosus, Cuvier in Cuvier and Valenciennes, 1830) (Sutter \& McIlwain, 1987) and as a consequence may choose to remain more stationary than to continually move. Few studies, however, have been conducted on this particular species or on their life history.

\subsubsection{Red Drum (Sciaenops ocellatus)}

Red drum are an important sport fish found throughout the Texas coast (Patillo et al., 1997; Scharf, 2000). While juveniles are predominately found within bays and estuaries, adults are typically found in offshore waters (Matlock, 1990; Stunz et al., 2002). Adults spawn near passes which connect to bays, making the Port Aransas ship channel a potentially important habitat for this species of fish (Stunz et al., 2001). Juvenile red drum migrate from bays to offshore waters and pass through jetty systems and inlets, potentially utilizing habitats found within the jetties. Laboratory mesocosm studies which compare seagrass habitats to sand have shown that red drum primarily select for seagrass (Stunz et al., 2001). Few if any studies have been conducted on other habitats found within and along jetty systems (Levin \& Stunz 2005). In our study, the only instance in which they selected for Leptogorgia sp. was within mesocosms containing sand vs. Leptogorgia sp. Red drum in mesocosms containing rock and Leptogorgia sp. did not show significant habitat selection for one habitat or the other. Hence, Red drum are opportunistic fish that prefer structured vs. non-structured habitat (i.e. seagrass/coral vs. rock/sand).

\section{Conclusion}

In summary, there are three species of Leptogorgia that have been observed in high abundances in jetties of Texas and yet their ecological importance is relatively unknown. Within this habitat the most abundant species of fish observed included the sergeant major and pinfish. Late summer sampling, as hypothesized, had the highest total fish counts. Fish observed on the jetty in moderate abundances were the mangrove snapper, pigfish, and spotfin mojarra. Mesocosm studies showed that Leptogorgia spp. are used as habitat by several species of fish. In accordance with the hypothesis, sergeant majors did preferentially select for Leptogorgia sp. habitat. Mangrove snapper also selected for Leptogorgia sp. habitat, although not as frequently has sergeant majors. Similarly, Red drum selected coral as habitat but their preference seemed to be associated with habitats that are vegetated vs. non-vegetated. Further, the presence of a predator did not alter habitat selection, implying a strong association with a specific habitat perhaps associated with olfactory cues (Parkyn, Murie, \& Sherwood, 2002; Dixson, Munday, \& Jones, 2010), environment-dependent mating preferences (Bacheler et al., 2009; Heuschele et al., 2009), environment-independent genetic influence (DeWitt \& Scheiner 2003) and/or chemical-mediated camouflage (Stachowicz \& Hay, 1999). This is contradictory to Stunz et al. (2001) who suggested that predators can significantly influence habitat selection. Overall, this study shows that Leptogorgia sp. is significant to some species of fish and should be better studied and perhaps considered as important fish habitat and protected. The life stages of fish utilizing Leptogorgia sp. should also be considered in future studies because habitat selection and food sources change with ontogenetic shifts.

\section{Acknowledgments}

We are grateful to the Texas Research Development Fund and the National Science Foundation for grants to KBS, and Texas Parks and Wildlife Department (TPWD) for licenses to KBS to collect corals. We thank L Squiers, M. White, and E. Williamson for review and advice in preparing this work.

\section{References}

Abu El-Nasr, T. M. (2015). Observations on the food and feeding habits of whipfin mojarra, Gerres filamentosus (Cuvier, 1829) in the Hurghada Red Sea. 10th International Environmental Conference, Zagazig University. Retrieved from 
https://scholar.google.com/citations?view_op=view_citation\&hl=en\&user=CylujqoAAAAJ\&citation_for_view=C ylujqoAAAAJ:zYLM7Y9cAGgC

Alves, J. A., Resende, A. C., Viaggi, J. C., Spach, H. L., Correia, A. T., \& Daros, F. (2016). Foraging behavior of the sergeant major (Abudefduf saxatilis) in a subtropical rocky reef, Brazil. Frontiers of Marine Science: Conference Abstract: XIX Iberian Symposium on Marine Biology Studies. https://doi:10.3389/conf.FMARS.2016.05.00111

Anonymous. (2021). Pinfish. Guidesly fishing. Retrieved from https://guidesly.com/fishing/fish-species/pinfish

Arceo-Carranza D., Vega-Cendejas, E. (2009). Spatial and temporal characterization of fish assemblages in a tropical coastal system influenced by freshwater inputs: northwestern Yucatan peninsula. Revista de Biologia Tropical, 57(1-2), 89-103. ISSN 0034-7744

Ackerman, J. L., Bellwood, D. R. (2002). Comparative efficiency of clove oil and rotenone for sampling tropical reef fish assemblages. Journal of Fish Biology, 60, 893-901. https://doi.org/10.1111/j.1095-8649.2002.tb02416.x

Bacheler, N. M., Gillum, Z. D., Gregalis, K. C., Schobernd, C. M., Schobernd, Z. H., \& Teer, B. Z. (2020). Spatial patterns in relative abundance and hábitat use of adult gray snapper off the Southeastern Coast of the United States. Marine and Coastal Fisheries, 12(3), 205-219. https://doi.org/10.1002/mcf2.10118

Bacheler, N. M., Paramore, L. M., Buckel, J. A., \& Hightower, J. E. (2009). Abiotic and biotic factors influence the hábitat use of an estuarine fish. Marine Ecology Progress Series, 377, 263-277. https://doi.org/10.3354/meps07805

Baron RM, Jordan LKB, Spieler RE (2004) Characterization of the marine fish assemblage associated with the nearshore hardbottom of Broward County, Florida, USA. Estuarine, Coastal and Shelf Science, 60(3), 431-443. https://doi.org/10.1016/j.ecss.2004.02.002

Beck, M. W., Heck, K. L., Able, K. W., Childers, D. L., Eggleston, D. B., Gillanders, B. M., Halpern, B., Hays, C. G., Hoshino, K., \& Minello, T. J. (2001). The identification, conservation, and management of estuarine and marine nurseries for fish and invertebrates: A better understanding of the habitats that serve as nurseries for marine species and the factors that create site-specific variability in nursery quality will improve conservation and management of these areas. Bioscience, 51(8), 633-641. https://doi.org/10.1641/0006-3568(2001)051[0633:TICAMO]2.0.CO;2

Beck, J. L., \& Rooker, J. R. (2012). Effect of predator exposure on the performance and survival of red drum (Sciaenops ocellatus). Environmental Biology of Fishes, 93, 267-276. doi.org/10.1007/s10641-011-9912-1

Blaber, S. J. M., \& Blaber, T. G. (2006). Factors affecting the distribution of juvenile estuarine and inshore fish. Journal of Fish Biology, 17(2), 143-162. https://doi.org/10.1111/j.1095-8649.1980.tb02749.x

Boyle, T. P., \& Fairchild, J. F. (1997). The role of mesocosm studies in ecological risk analysis. Ecological Applications, 7(4), 1099-1102. https://doi.org/10.1890/1051-0761(1997)007[1099:TROMSI]2.0.CO;2

Bohnsack, J. A., \& Bannerot, S. P. (1986). A stationary visual technique for quantitatively assessing community structure of coral reef fishes. NOAA/National Marine Fisheries Service, (NOAA Technical Report NMFS, 41). Retrieved from http://aquaticcommons.org/2781/1/tr41.pdf

Branco, C. W. C., Aguiaro, T., Esteves, F. A., \& Caramaschi, E. P. (1997). Food sources of the teleost Eucinostomus argenteus in two coastal lagoons of Brazil. Studies on Neotropical Fauna and Environment, 32(1), 33-40. https://doi.org/10.1076/snfe.32.1.33.13463

Britton, J. C., \& Morton, B. (1989). Shore ecology of the Gulf of Mexico. Austin, Texas. University of Texas. 387 p. https://doi.org/10.1126/science.247.4945.986-a

Burton, M. L. (2000). Age, growth, and mortality of gray snapper, Lutjanus griseus, from the east coast of Florida. Fishery Bulletin, 99(2), 254-256. Retrieved from https://www.researchgate.net/publication/216900045_Age_growth_and_mortality_of_gray_snapper_Lutjanus_gris eus_from_the_east_coast_of_Florida

Buxton, C. D., \& Smale, M. J. (1989). Abundance and distribution patterns of three temperate marine reef fish (Teleostei: Sparidae) in exploited and unexploited areas off the southern Cape coast. Journal of Applied Ecology, 26(2), 441-451. https://doi.org/10.2307/2404072

Cairns, S. D., \& Bayer, F. M. (2009). Chapter 13. Octocorallia (Cnidaria) of the Gulf of Mexico. In D. L. Felder and D. K. Camp (Eds.), Gulf of Mexico-Origins, Waters, and Biota. (Vol. 1, pp. 321-331). College Station, Texas: Texas A\&M Press.

Caldwell, Z. R., Zgliczynski, B. J., Williams, G. J., \& Sandin, S. A. (2016). Reef Fish Survey Techniques: Assessing the $\begin{array}{llllll}\text { Potential for Standardizing } & \text { Methodologies. PLOS ONE, } & \text { 11(4), } & \text { e153066. }\end{array}$ 
https://doi.org/10.1371/journal.pone.0153066

Cocheret de la Moriniere, E., Pollux, B. J. A., Nagelkerken, I., \& van der Velde, G. (2003). Diet shifts of Caribbean grunts (Haemulidae) and snappers (Lutjanidae) and the relation with nursery-to-coral reef migrations. Estuarine, Coastal and Shelf Science, 57(5-6), 1079-1089. https://doi.org/10.1016/S0272-7714(03)00011-8

Crowe, S., Blair, A., \& Pam, J. (2005). South Carolina comprehensive wildlife conservation strategy 2005-2010: Colorful sea whip Leptogorgia virgulata. South Carolina Department of Natural Resources. Retrieved from http://www.dnr.sc.gov/cwcs/pdf/Colorfulseawhip.pdf

Council of Science Editors. (2006). The CSE manual for authors, editors, and publishers. (7th ed.). Reston, VA. pp. 412-413.

Dahlberg, M. G. (1972). An ecological study of Georgia coastal fishes. Fishery Bulletin, 70(2), 323-353, Retrieved from https://spo.nmfs.noaa.gov/sites/default/files/pdf-content/1972/702/dahlberg.pdf

Davis, W. P., \& Birdsong, R. S. (1973). Coral reef fishes which forage in the water column. Helgoländer wissenschaftliche Meeresuntersuchungen, 24, 292-306. https://doi.org/10.1007/BF01609520

DeMartini, E. E., \& Roberts, D. (1982). An empirical test of biases in the rapid visual technique for species-time census of reef fish assemblages. Marine Biology, 70, 129-134. https://doi.org/10.1007/BF00397676

Denny, M. W., \& Paine, R. T. (1998). Celestial mechanics, sea-level changes, and intertidal ecology. The Biological Bulletin, 194(2), 108-115. https://doi.org/10.2307/1543040

DeWitt, T. J., \& Scheiner, S. M. (2003). Phenotypic plasticity. Functional and conceptual approaches. Oxford University Press, New York. ISBN: 0-19-513896-1

DeVictor, S. T. (2005). Leptogorgia virgulata (sea whip), L. hebes (regal sea fan) and their associates. Southeastern Regional Taxonomic Center. Charleston, South Carolina. Retrieved from http://www.dnr.sc.gov/marine/sertc/Leptogorgia.pdf

Dixson, D. L., Munday, P. L., \& Jones, G. P. (2010). Ocean acidification disrupts the innate ability of fish to detect predator olfactory cues. Ecology Letters, 13(1), 68-75. https://doi.org/10.1111/j.1461-0248.2009.01400.x

Drinkwater, K. F., \& Myers, R. A. (1987). Testing predictions of marine fish and shellfish landings from environmental variables. Canadian Journal of Fisheries and Aquatic Sciences, 44(99), 1568-1573. https://doi.org/10.1139/f87-189

Elliot, J. K., \& Leggett, W. C. (1996). The effect of temperature on predation rates of a fish (Gasterosteus aculeatus) and a jellyfish (Aurelia aurita) on larval capelin (Mallotus villosus). Canadian Journal of Fisheries and Aquatic Sciences, 53(6), 1393-1402. https://doi.org/10.1139/f96-049

Faletti, M. E., Chacin, D. H., Peake, J. A., MacDonald, T. C., \& Stallings, C. D. (2019). Population dynamics of pinfish in the eastern Gulf of Mexico (1998-2016). PLoS ONE, 14(8), e0221131. https://doi.org/10.1371/journal.pone.0221131

Fangue, N. A., Flaherty, K. E., Rummer, J. L., Cole, G., Hansen, K. S., Hinote, R., Noel, B.L., Wallman, H., \& Bennett, W. A. (2001). Temperature and hypoxia tolerance of selected fishes from a hyperthermal rockpool in the Dry Tortugas, with notes on diversity and behavior. Caribbean Journal of Science, 37(1-2), 81-87. http://dx.doi.org/10.18475/cjos.v47i3.a1

Ferro, F., Jordan, L. K. B., \& Spieler, R. E. (2005). The marine fishes of Broward County, Florida: Final report of 1998-2002 survey results. NOAA Technical Memorandum NMFS-SEFSC-532 73 p. ISBN-13: 978-1125409626

Fischer, P. (2000). Test of competitive interactions for space between two benthic fish species, Burbot Lota lota and Stone Loach Barbatula barbatula. Environmental Biology of Fishes, 58:439-446. https://doi.org/10.1023/A:1007631107521

Fischer, J.L, Roseman, E.F., Mayer, C.M., \& Qian, S. (2018). Effectiveness of shallow water habitat remediation for improving fish habitat in a large temperate river. Ecological Engineering, 123, 54-64. doi.org/10.1016/j.ecoleng.2018.07.022

Froeschke, J. T., Allen, L. G., \& Pondella, D. J. (2005). The reef fish assemblage of the outer Los Angeles federal breakwater, 2002-2003. Bulletin, Southern California Academy of Sciences, 104(2), 63-74. https://doi.org/10.3160/0038-3872(2005)104[63:TRFAOT]2.0.CO;2

Fuiman, L.A. (1994). The interplay of ontogeny and scaling in the interactions of fish larvae and their predators. Journal of Fish Biology, 45(Suppl. 1A), 55-79. https://doi.org/10.1111/j.1095-8649.1994.tb01084.x

Harley, C. D. G., \& Helmuth, B. S. T. (2003). Local- and regional-scale effects of wave exposure, thermal stress, and absolute versus effective shore level on patterns of intertidal zonation. Limnology and Oceanography, 48(4), 
1498-1508. https://doi.org/10.4319/lo.2003.48.4.1498

Heggenes, J. (1996). Habitat selection by brown trout (Salmo trutta) and young Atlantic salmon (S. salar) in streams: static and dynamic hydraulic modeling. Regulated Rivers: Research and Management, 12(2-3), 155-169. https://doi.org/10.1002/(SICI)1099-1646(199603)12:2/3<155::AID-RRR387>3.0.CO;2-D

Hettler, W. F. Jr. (1989). Food habits of juveniles of spotted seatrout and gray snapper in western Florida Bay. Bulletin of Marine Science, 44(1), 155-162.

Heuschele, J., Mannerla, M., Gienapp, P., \& Candolin, U. (2009). Environment-dependent use of mate choice cues in sticklebacks. Behavioral Ecology, 20(6), 1223-1227. https://doi.org/10.1093/beheco/arp123

Hoese, H. D., \& Moore, R. H. (1998). Fishes of the Gulf of Mexico, Texas, Louisiana, and adjacent waters. Texas A\&M University Press. 416 p. ISBN-13: 978-0890967379

Hughes, B. B., Levey, M.D., Brown, J.A., Fountain, M.C., Carlisle, A.B., Litvin, S.Y., Greene, C.M., Heady, W.N., \& Gleason, M.G. (2014). Nursery Functions of U.S. West Coast Estuaries: The State of Knowledge for Juveniles of Focal Invertebrate and Fish Species. The Nature Conservancy, Arlington, VA. 168pp. Retrieved from https://www.scienceforconservation.org/assets/downloads/Nursery-Functions-West_Coast-Estuaries-2014.pdf

Jaureguizar, A.J., DeWysiecki, A.M., Camiolo, M.D., \& Clara, M.L. (2021). Inter-annual fluctuation in the population structure of an estuarine fish: Influence of environmental drivers. Journal of Marine Systems, 218, 103526. https://doi.org/10.1016/j.jmarsys.2021.103526

Jefferson, J. (2021). Heck of a speck: Spotted seatrout, or specks, are plentiful, reat sport and delicious. Texas Parks and Wildlife. April 2021. Retrieved from https://tpwmagazine.com/archive/2021/apr/ed_3_seatrout/

Kerschner, B. A., Peterson, M. S., \& Gilmore, R. G. (1985). Ecotopic and ontogenetic trophic variation in Mojarras (Pisces: Gerreidae). Estuaries, 8, 311-322. https://doi.org/10.2307/1351492

Leclercq, N., Gattuso, J., \& Jaubert, J. (1999). Measurement of oxygen metabolism in open-top aquatic mesocosms: application to a coral reef community. Marine Ecology Progress Series, 177, 299-304. https://doi.org/10.3354/meps177299

Levin, P., Petrik, R., \& Malone, J. (1997). Interactive effects of habitat selection, food supply and predation on recruitment of an estuarine fish. Oecologia, 112, 55-63. https://doi.org/10.1007/s004420050283

Levin, P. S., \& Stunz, G. W. (2005) Habitat triage for exploited fishes: can we identify essential "Essential Fish Habitat?" estuarine. Estuarine, Coastal and Shelf Science, 64(1), 70-78. https://doi.org/10.1016/j.ecss.2005.02.007

Lyndeman, K. C., \& Snyder, D. B. (1999). Nearshore hardbottom fishes of southeast Florida and effects of habitat burial by dredging. Fishery Bulletin, 97(3), 508-525. Retrieved from https://spo.nmfs.noaa.gov/sites/default/files/09lindem.pdf

Matlock, G.C. (1990). The life history of red drum. In: G.W. Chamberlain, R.J. Midget, \& M.G. Haby (Eds.), Red Drum Aquaculture, pp. 1-21. Texas A\&M Sea Grant College Program No. TAMU-SG-90-603. College Station, Texas, United States of America.

Main, K. L. (1987). Predator avoidance in seagrass meadows: Prey behavior, microhabitat selection and cryptic coloration. Ecology, 68(1), 170-180. https://doi.org/10.2307/1938817

Mendelssohn, I.A., Byrnes, M.R., Kneib, R.T., \& Vittor, B.A. (2017). Coastal Habitats of the Gulf of Mexico. In: Ward C. (Eds). Habitats and biota of the Gulf of Mexico: Before the Deepwater Horizon oil spill. Springer, New York, NY. https://doi.org/10.1007/978-1-4939-3447-8_6

Merilaita, S., Tuomi, J., \& Jormalainen, V. (1999). Optimization of cryptic coloration in heterogeneous habitats. Biological Journal of the Linnean Society, 67(2), 151-161. https://doi.org/10.1111/j.1095-8312.1999.tb01858.x

Muncy, R. J. (1984). Species profiles: Life histories and environmental requirements of coastal fishes and invertebrates (Gulf of Mexico): Pinfish. U.S. Fish and Wildlife Service FWS/OBs-82/11.26. U.S. Army Corps of Engineers, TR ER-82-7, 18 pp.

Nagelkerken, W. P. (1974). On the occurrence of fishes in relation to corals in Curaçao. Studies on the Fauna of Curacao and other Caribbean Islands, 45(1), 118-141. Retrieved from https://repository.naturalis.nl/pub/506117

Nagelkerken, I., van der Velde, G., Gorissen, M. W., Meijer, G. J., van Hoft, T., \& den Hartog, C. (2000). Importance of mangroves, seagrass beds and the shallow coral reef as nursery for important coral reef fishes, using a visual census technique. Estuarine, Coastal and Shelf Science, 51(1), 31-44. https://doi.org/10.1006/ecss.2000.0617

Nagelkerken, I., Kleijnen, S., Klop, T., van den Brand, R. A. C. J., Cocheret de la Moriniere, E., \& van der Velde, G. 
(2001). Dependence of Caribbean reef fishes on mangroves and seagrass beds as nursery habitats: a comparison of fish faunas between bays with and without mangroves/seagrass beds. Marine Ecology Progress Series, 214, $225-235$. https://doi.org/10.3354/meps214225

Neahr, T. A., Stunz, G. W., \& Minello, T. J. (2010). Habitat use patterns of newly settled spotted seatrout in estuaries of the north-western Gulf of Mexico. Fisheries Management and Ecology, 17, 404-413. https://doi.org/10.1111/j.1365-2400.2010.00733.x

National Climatic Data Center (NCDC). (2021). 1981-2010 - Normals:Port Aransas, TX US", NOAA, 2021. Retrieved from https://www.ncdc.noaa.gov/cdo-web/datatools/normals

Ohs, L.C., DiMaggio, M.A., \& Grabe, S.W. (2011). Species profile: Pinfish, Lagodon rhomboids. Southern Regional Aquaculture Center Publication, No. $7210 . \quad 6 \quad$ pp. Retreived from https://fisheries.tamu.edu/aquaculture/species-profiles/

Ohs, L. C., Grabe, S. W., \& DiMaggio, M. A. (2018). Candidate species for Florida aquaculture: pinfish Lagodon rhomboids. University of Florida, IFAS Extension. 5pp. Retrieved from https://edis.ifas.ufl.edu/pdf/FA/FA16800.pdf

Orlando, S. P. Jr., Rozas, L. P., Ward, G. H., \& Klein, C. J. (1993). Salinity characteristics of Gulf of Mexico estuaries. U.S. Department of Commerce, National Oceanic and Atmospheric Administration, Office of Ocean Resources Conservation and Assessment. Silver Spring, MD. 209 pp.

Pais, M. P., \& Lino, P. (2018). Effect of underwater visual survey methodology on bias and precision of fish counts: a simulation approach. PeerJ, 2018; 6: e5378. https://doi.org/10.7717/peerj.5378

Parkyn, D. C., Murie, D. J., \& Sherwood, E. T. (2002). Salinity preference in hatchery-reared juvenile red drum. The Scientific World Journal, 2, 326-1331. https://doi.org/10.1100/tsw.2002.347

Patillo, M. E., Czapla, T. E., Nelson, D. M., \& Monaco, M. E. (1997). Red Drum: Distribution and abundance of fishes and invertebrates in Gulf of Mexico estuaries, Volume II: Species life history summaries. Estuarine living marine resources program, Report No. 11. NOAA. P. 291-304. Available from http://hdl.handle.net/1969.3/25790

Peters, K. M., \& McMichael, R. H. (1990). Early life history of the Black Drum, Pogonias cromis (Pices; Sciaenidae) in Tampa Bay, Florida. Gulf of Mexico Science, 11(1), 39-58. https://doi.org/10.18785/negs.1101.05

Phelps, R. P., \& Williams, E. H. Jr. (1995). New records of Caribbean fishes in Alabama. Caribbean Journal of Science, 31(1-2), 152-154.

Póda, C., \& Jordán, F. (2020). Aquatic food web research in mesocosms: a literature survey: Aquatic food web research in mesocosms. Journal of Limnology, 79(3).

Potthoff, M. T., \& Allen, D. M. (2003). Site fidelity, home range, and tidal migrations of juvenile pinfish, Lagodon rhomboides, in salt marsh creeks. Environmental Biology of Fishes, 67, 231-240. https://doi.org/10.1023/A:1025874712710

Powers, M. J., Peterson, C. H., Summerson, H. C., \& Powers, S. P. (2007). Macroalgal growth on bivalve aquaculture netting enhances nursery habitat for mobile invertebrates and juvenile fishes. Marine Ecology Progress Series, 339, 109-122. https://doi.org/10.3354/meps339109

Régnier, T., Gibb, F. M., \& Wright, P. J. (2019). Understanding temperature effects on recruitment in the context of trophic mismatch. Scientific Reports, 9, 15179 https://doi.org/10.1038/s41598-019-51296-5

Robertson, D. R. (1988). Settlement and population dynamics of Abudefduf saxatilis on patch reefs in Caribbean Pananma. Proceedings of the Sixth International Coral Reef Symposium, Australia, 2, 839-844. Retrieved from http://www.reefbase.org/resource_center/publication/icrs.aspx

Rooker, J. R., Holt, G. J., \& Holt, S. A. (1998.) Vulnerability of newly settled red drum (Scieanops ocellatus) to predatory fish: is early-life survival enhanced by seagrass meadows? Marine Biology, 131, 145-151. doi.org/10.1007/s002270050305

Rosenzweig, M. L. (1981). A theory of habitat selection. Ecology, 62(2), 327-335. https://doi.org/10.2307/1936707

Rummer, J. L., Fangue, N. A., Jordan, H. L., Tiffany, B. N., Blansit, K. J., Gallerher, S., ... \& Bennett, W. A. (2009). Physiological tolerance to hyperthermia and hypoxia and effects on species richness and distribution of rockpool fishes of Loggerhead Key, Dry Tortugas National Park. Journal of Experimental Marine Biology and Ecology, 371(2), 155-162. https://doi.org/10.1016/j.jembe.2009.01.015

Sale, P. F., \& Sharpe, B. J. (1983). Correction for bias in visual transect censuses of coral reef fishes. Coral Reefs, 2 , 37-42. 
https://doi.org/10.1007/BF00304730

Scharf F. S. (2000). Patterns in abundance, growth, and mortality of juvenile red drum across estuaries on the Texas coast with implications for recruitment and stock enhancement. Transactions of the American Fisheries Society, 129(6), 1207-1222. https://doi.org/10.1577/1548-8659(2000)129<1207:PIAGAM>2.0.CO;2

Schweitzer, C. C., \& Stevens, B. G. (2019). The relationship between fish abundance and benthic community structure on artificial reefs in the Mid-Atlantic Bight, and the importance of sea whip corals Leptogorgia virgulata. PeerJ, 7, e7277. https://doi.org/10.7717/peerj.7277

Schultz, R. L. (1962). Survey of the invertebrate species present in Aransas and Copano Bays. Texas Parks and Wildlife Department, Coastal Fisheries Job Report, Fisheries Investigations in the Aransas-Copano Bay System, Project No. M-6-R-2. Job B-2. Texas Parks and Wildlife Department, Austin, Texas. 12 pp. Retrieved from https://citeseerx.ist.psu.edu/viewdoc/download?doi=10.1.1.670.5261\&rep=rep1\&type=pdf

Shervette, V. R., Ibarra, N., \& Gelwick, F. (2007). Influences of salinity on growth and survival of juvenile pinfish Lagodon rhomboides (Linnaeus). Environmental Biology of Fishes, 78, 125-134. https://doi.org/10.1007/s10641-006-9082-8

Silvestri, S., Figueroa, D. F., Hicks, D., \& Figueroa, N. M. (2019). Mitogenomic phylogenetic analyses of Leptogorgia virgulata and Leptogorgia hebes (Anthozoa: Octocorallia) from the Gulf of Mexico provides insight on Gorgoniidae divergence between Pacific and Atlantic lineages. Ecology and Evolution, 00, 1-16. https://doi.org/10.1002/ece3.5847

Smith, M. P. L. (1988). Effects of observer swimming speed on sample counts of temperate rocky reef fish assemblages. Marine Ecology Progress Series, 43, 223-231. https://doi.org/10.3354/meps043223

Snow, R. A., Shoup, D. E., \& Porta, M. J. (2018). Effects of turbidity on prey selection and foraging rate of hatchery-reared juvenile tiger Muskellunge. North American Journal of Fisheries Management, 38, 487-492. https://doi.org/10.1002/nafm.10053

Stachowicz, J. J., \& Hay, M. E. (1999). Reducing predation through chemically mediated camouflage: Indirect effects of $\begin{array}{lllll}\text { plant defenses } & \text { on } & \text { herbivores. }\end{array}$ https://doi.org/10.1890/0012-9658(1999)080[0495:RPTCMC]2.0.CO;2

Street, M. W., Deaton, A. S., Chappell, W. S., \& Mooreside, P. D. (2005). North Carolina Coastal Habitat Protection Plan. North Carolina Department of Environment and Natural Resources, Division of Marine Fisheries, Morehead City, NC. 660 pp. Retrieved from https://digital.ncdcr.gov/digital/collection/p16062coll9/id/202913

Stoner, A. W. (1982). Feeding ecology of the Lagodon rhomboides (Pisces: Sparidae): variation and functional responses. Fishery Bulletin, 78(2), 337-352. https://spo.nmfs.noaa.gov/sites/default/files/pdf-content/1980/782/stoner.pdf

Stunz, G. W., \& Minello, T. J. (2001). Habitat-related predation on juvenile wild-caught and hatchery-reared red drum Sciaenops ocellatus (Linneaus). Journal of Experimental Marine Biology and Ecology, 260(1), 13-25. https://doi.org/10.1016/S0022-0981(01)00248-9

Stunz, G. W., Levin, P. S., \& Minello, T. J. (2001). Selection of estuarine nursery habitats by wild-caught and hatchery-reared juvenile red drum in laboratory mesocosms. Environmental Biology of Fishes, 61, 305-313. https://doi.org/10.1023/A:1010874629788

Stunz, G. W., Minello, T. J, \& Levin, P. S. (2002). A comparison of early juvenile red drum densities among various habitat types in Galveston Bay, Texas. Estuaries, 25, 76-85. https://doi.org/10.1007/BF02696051

Sutter, F. C., \& McIlwain, T. D. (1987). Species profiles: life histories and environmental requirements of coastal fisheries and invertebrates (Gulf of Mexico): pigfish. U.S. Fish and Wildlife Service Biological Report 82. 11pp. Retrieved from https://www.osti.gov/biblio/6242643

Tabb, D. C. (1958). Investigation of possible effects on the marine environment of dredging and filling the ragged keys. Report to the Florida state board of conservation. 14 pp.

Texas Coastal Ocean Observation Network (TCOON), Division of Nearshore Research, Conrad Blucher Institute for Surveying and Science, Texas A\&M University - Corpus Christi. 2009. Retrieved from http://lighthouse.tamucc.edu/TCOON/HomePage

Thanopoulou, Z., Sini, M., Vatikiotis, K., Katsoupis, C., Dimitrakopoulos, P. G., \& Katsanevakis, S. (2018). How many fish? Comparison of two underwater visual sampling methods for monitoring fish communities. PeerJ, 6, e5066. doi.org/10.7717/peerj.5066 
Tissot, P. E. (2005). Study of a possible link between drowning and near-drowning events and surf conditions in South Texas. Final report submitted to Texas Sea Grant. 56 pp. Retrieved from https://www.cbi.tamucc.edu/wp-content/uploads/Drowning-and-Surf-Conditions-Report.pdf

Wenker, R. P., Stevens, B. G. (2020). Sea whip coral Leptogorgia virgulata in the Mid-Atlantic Bight: Colony complexity, age, and growth. PeerJ 8, e8372 https://doi.org/10.7717/peerj.8372

Werner, E. E., Gilliam, J. F., Hall, D. J., \& Mittlebach, G. G. (1983). An experimental test of the effects of predation risk on habitat use in fish. Ecology, 64(6) 1540-1548. https://doi.org/10.2307/1937508

Wethey, D. S. (1983). Geographic limits and local zonation: The barnacles Semibalanus (balanus) and Chthamalus in New England. The Biological Bulletin, 165(1), 330-341. https://doi.org/10.2307/1541373

White, M., \& Strychar, K. B. (2011). Coral as environmental bioindicators: Ecological and morphological effects of gasoline on Gorgonian corals, Leptogorgia virgulata. International Journal of Biology, 3(1), 63-73. https://doi.org/10.5539/ijb.v3n1p63

Wicksten, M. K., \& Cox. C. (2011). Invertebrates associated with gorgonians in the northern Gulf of Mexico. Marine Biodiversity Records, 4, 1-9. https://doi.org/10.1017/S1755267211000741

Williamson, E. A., Strychar, K. B., \& Withers, K. (2011). Distribution of the Gorgonian genus Leptogorgia at two jetties in the Northwestern Gulf of Mexico. Gulf of Mexico Science, 29(2), 126-130. https://doi.org/10.18785/goms.2902.06

Williamson, E. A., Strychar, K. B., Withers, K., \& Sterba-Boatwright, B. (2011). Effects of salinity and sedimentation on the Gorgonian coral Leptogorgia virgulata (Lamarck 1815). Journal of Experimental Marine Biology and Ecology, 409(1-2), 331-338. https://doi.org/10.1016/j.jembe.2011.09.014

Willis, T. J. (2001). Visual census methods underestimate density and diversity of cryptic reef fish. Journal of Fish Biology, 59, 1408-1411. https://doi.org/10.1006/jfbi.2001.1721

Wuenschel, M. J., Jugovich, A. R., \& Hare, J. A. (2004). Effect of temperature and salinity on the energetic of juvenile gray snapper (Lutjanus griseus): implications for nursery habitat value. Journal of Experimental Marine Biology and Ecology, 312(2), 333-347. https://doi.org/10.1016/j.jembe.2004.07.007

Yeager, L. A., Layman, C. A., \& Hammerschlag-Peyer, C. M. (2014). Diet variation of a generalist fish predator, grey snapper Lutjanus griseus, across an estuarine gradient: trade-offs of quantity for quality? Journal of Fish Biology, 85, 264-277. https://doi.org/10.1111/jfb.12416

Zar, J. H. (2010). Biostatistical analysis, 5th ed. Upper Saddle River, N.J.: Prentice-Hall/Pearson. 960 pp. ISBN-13: 9780321656865 .

\section{Appendix A}

Table A1. All fish species recorded at each stationary sampling observation site during the early fall (September-October), late spring (May-June), and late summer (August-September) sampling at the Port Aransas, Texas south jetty (Note: * denotes depths greater than $1.5 \mathrm{~m}$ ). Blank spaces indicate that no fish were observed at that specific site.

\begin{tabular}{|c|c|c|c|c|c|c|c|c|c|c|c|c|c|}
\hline Fish Observed & $\begin{array}{c}\text { Site } \\
1\end{array}$ & $\begin{array}{c}\text { Site } \\
2\end{array}$ & $\begin{array}{c}\text { Site } \\
\mathbf{3}\end{array}$ & $\begin{array}{c}\text { Site } \\
4\end{array}$ & $\begin{array}{c}\text { Site } \\
5\end{array}$ & $\begin{array}{c}\text { Site } \\
6\end{array}$ & $\begin{array}{c}\text { Site } \\
7\end{array}$ & $\begin{array}{c}\text { Site } \\
8\end{array}$ & $\begin{array}{c}\text { Site } \\
9\end{array}$ & $\begin{array}{c}\text { Site } \\
\mathbf{1 0}\end{array}$ & $\begin{array}{c}\text { Site } \\
11\end{array}$ & $\begin{array}{c}\text { Site } \\
12\end{array}$ & Total \\
\hline \multicolumn{14}{|c|}{ Early Fall (September to October) } \\
\hline Sergeant Major & 8 & 7 & 18 & 36 & 5 & 8 & 24 & 29 & 3 & 9 & 38 & & 185 \\
\hline Pinfish & 5 & 2 & 11 & 42 & 12 & 21 & 35 & 17 & & 3 & 16 & 1 & 165 \\
\hline Cocoa Damsel & & & & $1 *$ & $1 *$ & & & & & & 4 & & 10 \\
\hline Mangrove Snapper & 4 & 2 & 4 & 2 & 2 & & 2 & 1 & & & & 1 & 18 \\
\hline Spotfin Mojarra & 1 & & & & & & & & & & & & 1 \\
\hline Pigfish & & & 1 & & & & & & & & 2 & & 3 \\
\hline Black Drum & $1 *$ & & & & & & & & & & & & 1 \\
\hline Spotfin Butterflyfish & & & & & & & & & & & & & 0 \\
\hline Rock Hind & & 1 & & & 1 & & & & 1 & 1 & 1 & & 5 \\
\hline Spadefish & & & & & $6^{*}$ & & & & & & & & 6 \\
\hline Sheepshead & & & & & & $1 *$ & $1 *$ & & & & & & 2 \\
\hline Snook & & & & & & & $1 *$ & & & & & & 1 \\
\hline Hairy Blenny & & & & & & & & 1 & & & & & 1 \\
\hline
\end{tabular}


Mackeral 0

Slippery Dick Wrasse

0

Bucktooth Parrotfish

0

Flagfin Mojarra

\section{Late Spring (May to June)}

Sergeant Major

Pinfish

Cocoa Damsel

Mangrove Snapper

Spotfin Mojarra

Pigfish

Black Drum

Spotfin Butterflyfish

Rock Hind

Spadefish

Sheepshead

Snook

$2 *$

8

$\begin{array}{cccccc}6 * & 3 & 3 * & 2 * & 4 \\ 1 & & & & \end{array}$

10

$3 * \quad 6 \quad 3$

4
3

3

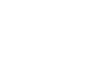

$\begin{array}{lll}2 & 2\end{array}$

$\begin{array}{ll}2 & 2 \\ -12 & 0\end{array}$

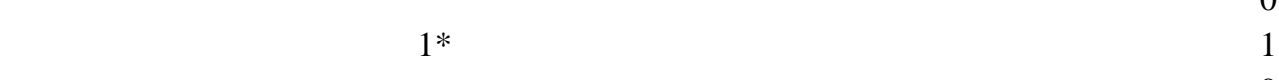

$1 * \quad 3$

Hairy Blenny

Mackeral

1

Slippery Dick Wrasse

Bucktooth Parrotfish

Flagfin Mojarra

\begin{tabular}{|c|c|c|c|c|c|c|c|c|c|c|c|c|c|}
\hline \multicolumn{14}{|c|}{ Late Summer (July-August) } \\
\hline Sergeant Major & 42 & 16 & 17 & 22 & 9 & 42 & 40 & 4 & 20 & 64 & 29 & 42 & 347 \\
\hline Pinfish & & & & & & $1 *$ & $1 *$ & $8 *$ & $3 *$ & $3 *$ & $5 *$ & & 21 \\
\hline Cocoa Damsel & 1 & 2 & & & 2 & & & 2 & & & & & 7 \\
\hline Mangrove Snapper & & & $4 *$ & & $1^{*}$ & & $1 *$ & 1 & $5 *$ & 5 & 1 & & 25 \\
\hline Spotfin Mojarra & & & & & & & & & 20 & 1 & 12 & & 33 \\
\hline Pigfish & & & & & & & & & & & & & 0 \\
\hline Black Drum & & & & & & & & & & & & & 0 \\
\hline Spotfin Butterflyfish & & & & & & & & & & 1 & & & 1 \\
\hline Rock Hind & & & & & 1 & 1 & 1 & & 1 & & & 1 & 5 \\
\hline Spadefish & & & & & & & & & & & & & 0 \\
\hline Sheepshead & & & 1 & & & & & & & & & & 1 \\
\hline Snook & & & & & & & & & & & & & 0 \\
\hline Hairy Blenny & & & & & & & & & & & & & 0 \\
\hline Mackeral & & & & & & & & & & & & & 0 \\
\hline Slippery Dick Wrasse & & & & & & & 2 & & & & 1 & & 3 \\
\hline Bucktooth Parrotfish & & & & & & & & & & 1 & & 1 & 2 \\
\hline Flagfin Mojarra & & & & & & & & & & & 3 & & 3 \\
\hline
\end{tabular}

\section{Copyrights}

Copyright for this article is retained by the author(s), with first publication rights granted to the journal.

This is an open-access article distributed under the terms and conditions of the Creative Commons Attribution license (http://creativecommons.org/licenses/by/4.0/). 